\title{
Complexity in Structured Finance: Financial Wizardry or Smoke and Mirrors?*
}

\author{
Andra Ghent Walter Torous Rossen Valkanov \\ ASU MIT UCSD \\ aghent@asu.edu wtorous@mit.edurvalkanov@ucsd.edu
}

This draft: January 8, 2014.

First draft: September 13, 2013

\begin{abstract}
We use data from prospectus supplements to create measures of the complexity of securitized products. We use these measures to investigate whether and to what extent complexity plays a role in the performance and pricing of mortgage-backed securities. We find that securities in more complex deals default more. However, yields of more complex securities are not higher at issuance indicating that investors do not perceive such assets as more likely to default. Furthermore, rating agencies are more lenient in rating complex deals. Our results indicate that issuers use complexity as a sales device rather than to create higher quality assets.
\end{abstract}

JEL Codes: G12, G14, G21, G24.

\footnotetext{
*We thank Mark Adelson, Andy Davidson, Sean Flynn, John Griffin, Harrison Hong, Kjell Nybor, Per Östberg, Amit Seru, Kumar Venkataraman, Sunil Wahal, Joseph Zechner, and seminar audiences at ASU, University of Luxemburg, and University of Zurich for helpful suggestions. Yue Cao and Andrew Farber provided excellent research assistance. Valkanov benefited from the hospitality of the University of Zurich while writing parts of this paper.
} 


\section{Introduction}

Mortgage-backed securities (MBS) are created by the pooling and tranching of loans into multiple securities oftentimes with various credit enhancements. Their structures are detailed in lengthy prospectuses and prospectus supplements (many of them hundreds of pages long) describing the collateral, the allocation of cashflows from the pool of loans to the securities in various states of nature, the rating of the securities, and other structural features (e.g., collateral groups, subordination, and cross-collateralization). These non-standardized contingent contracts place considerable informational demands on investors. In other words, they are complex.

If investors face constraints in acquiring or processing information then complexity ought to play a role in the pricing and performance of MBS. As complex MBS were at the center of the 2007-2009 financial crisis and markets for many securitized products collapsed, it is reasonable to ask what role, if any, complexity plays in structured finance. ${ }^{1}$ For instance, do complex securities default more frequently? Are they priced at a premium or at a discount? More fundamentally, is complexity a byproduct of issuers' attempts to tailor new securities to investors' preferences and improve risk sharing? Alternatively, is it used as smoke and mirrors to sell risky securities at inflated prices? Answering these questions will deepen our understanding of financial decision making under informational and cognitive constraints.

In this paper, we study the role complexity plays in the performance and pricing of structured, securitized products. We start by constructing five variables that proxy for the complexity of these products. For each deal, we collect data on (i) the number of collateral groups and (ii) the number of securities (i.e., tranches). In addition, using the prospectus supplement of a deal, we count the total number of pages (iii) in the prospectus supplement, (iv) the number of pages specifically describing the collateral, and (v) the number of pages specifically describing the division of cashflows from the pool of loans to the securities. The prospectus-based variables are hand-collected and their ability to proxy for complexity is supported by Loughran and McDonald (forthcoming). The five variables are designed to measure the informational demands MBS deals impose on investors and the intricacies in structure across deals. While correlated, they capture different facets of the MBS products. Thus, we also provide a summary measure of complexity - an index of complexity - that

\footnotetext{
${ }^{1}$ For example, discussions of security complexity feature prominently in the 2011 Financial Crisis Inquiry Commission's Report.
} 
synthesizes the information available in our five individual variables.

We then use data from the home equity asset-backed securities (ABS) market, a subsegment of the larger MBS market, together with our measures of complexity to establish the following facts. First, controlling for the year the security is issued, securities of more complex deals default more $e x$ post and are hence riskier. A one standard deviation increase in the complexity index is associated with a three percentage point increase in the risk of default. The relation between complexity and security performance is particularly strong for securities rated AAA at issuance. For these securities, a one standard deviation increase in complexity is associated with a seven percentage point higher likelihood of default. The higher likelihood of default is economically meaningful as it represents a $19 \%$ increase relative to the mean default level on AAA securities. ${ }^{2}$

Second, securities of more complex deals have lower spreads at issuance indicating that, ex ante, investors did not perceive them as riskier. This finding is intriguing because, in light of the higher default rates of complex deals, we anticipate observing higher, rather than lower, spreads as compensation for additional credit risk. Third, credit rating agencies (CRAs) rate more complex deals more favorably from the perspective of issuers. The favorable ratings do not, however, explain the greater default propensities since we control for the treatment of the security by the CRAs in our regressions. Fourth, the fraction of loans in a group that terminate through foreclosure, a proxy for collateral quality, is higher for more complex deals after controlling for observable collateral characteristics. Finally, the level of complexity in ABS deals increased steadily throughout the 2000s.

The findings that more complex securities default more, and that this greater default risk is not priced, indicate that large institutional investors, who are the primary participants in the ABS market, do not fully process the information in elaborate securities. As such, they do not demand a risk premium to hold more complex securities that will default more often. Issuers, aware of the limitations of market participants, can use complexity to price low quality securities at par with high quality securities. In other words, it literally pays issuers to be complex. If, alternatively, investors fully process information about the securities, issuers would either have to accept a lower price for more complex securities or would not be able to sell them at all.

\footnotetext{
${ }^{2}$ The mean default rate in our AAA subsample is 36 percentage points. A seven percentage point increase in the likelihood of default therefore represents a $19 \%(7 / 36)$ higher likelihood of default.
} 
Our results contribute to a growing literature documenting that market participants ignore publicly available information. In the context of the stock market, this results in stock return predictability (e.g., DellaVigna and Pollet (2007, 2009), Hong, Torous, and Valkanov (2007), Hirshleifer, Lim, and Teoh (2009), and Cohen and Lou (2012)) ${ }^{3}$. Importantly, that literature focuses mainly on unsophisticated retail investors and their boundedly rational decision-making. Our results show that sophisticated market participants can also be boundedly rational when the processing of intricate financial information is excessively costly. The evidence also suggests that, rather than only facing difficulties processing information about the underlying assets in a timely fashion, investors either lack the incentives for or have problems understanding the structure of securities themselves. In sum, the evidence from the ABS market makes it clear that the complexity of financial information ought to play a role in defining and understanding bounded rationality.

We next consider whether our findings can be explained by classic models of security design that posit fully rational investors. Theories that emphasize completing the market (e.g., Allen and Gale $(1988,1991)$ ), or “tailoring" assets to particular investors' preferences, do not directly address security complexity and, as Duffie and Rahi (1995) point out, have "relatively few concrete or normative predictive results." Within the context of these models, however, complexity can be understood as a byproduct of designing new securities to complete the market. We find some evidence of tailoring securities to satisfy the Government Sponsored Enterprises' (GSEs') demand consistent with spanning theories but, in general, distinct loan pools within deals are quite similar to one another. Furthermore, tailoring theories do not predict that more complex securities should default more or get better ratings.

Complexity also arises as a byproduct in models that emphasize the information sensitivities of securities (e.g., Gorton and Pennacchi (1990) and Boot and Thakor (1993)). These models illustrate the need to create multiple securities from the same collateral. Consistent with these models, we find securities with different information sensitivities within the same deal. Nevertheless, it is unclear how these models predict the sheer number of informationally sensitive and insensitive securities that we observe: the average deal in our sample has 16 securities and one deal has 75 . Additionally,

\footnotetext{
${ }^{3}$ Barberis and Thaler (2003) survey work demonstrating bounded rationality in financial markets. Additional recent papers in this literature include Huberman and Regev (2001), Hou (2007), Barber and Odean (2008), Cohen and Frazzini (2008), and Menzly and Ozbas (2010). These papers are based on theoretical work by Merton (1987), Hong and Stein (1999), Sims (2003), and Hirshleifer and Teoh (2003).
} 
theories of security design based on information sensitivity do not predict more default or ratings inflation among more complex securities.

Our results are important for several additional reasons. First, the finding that more complex deals are rated more favorably shows that the CRAs do not simplify the structure of complex securities into one meaningful metric, the credit rating, which in turn drives prices. Hence, CRAs do not obviate the need for investors to understand complex securities. Without knowing more about the intricacies of how CRAs rate these securities, we cannot conclude that credit analysts were confused by the complexity of deals. Nevertheless, our findings suggests that during the subprime boom, the CRAs exacerbated rather than mitigated problems investors had in understanding complex securities.

Second, the failure of both spreads and credit ratings to reflect the greater risks associated with complexity indicates that there may be welfare benefits from standardizing securitized products in the sense of Gale (1992). Such standardization may be particularly important if Fannie Mae and Freddie Mac play less of a role in the mortgage market going forward. Securities issued by the GSEs (agency MBS) are quite simple by our measures: their prospectus supplements are short, there are few securities within a deal, and they usually only have one collateral group. The simplicity of agency MBS may help explain the relatively successful functioning, historically, of the agency MBS market.

Third, our findings are important for understanding the boom in subprime securities. These securities are primarily issued by non-GSE financial institutions and are commonly known as privatelabel MBS (PLMBS). As we show in Figure 1, the market for PLMBS, the vast majority of which were sold to investors as non-prime securities, grew more than ten-fold between 1999 and 2006 . Furthermore, as of summer 2013, the majority of these securities defaulted, including more than a third of securities rated AAA at issuance (see Table 1). Why did investors pour so much money into assets that ultimately proved so disastrous? One explanation is that, as argued by Gennaioli, Shleifer, and Vishny (2012), they neglected the risk of a widespread decline in home prices. Indeed, there is evidence that subprime executives themselves did not expect that home prices would fall substantially (Cheng, Raina, and Xiong (2013)). Such neglect likely decreased investors' willingness to allocate the resources required to fully understand the structure of these securities. Our findings imply that a contributing factor to the subprime boom was the complexity of the securities. 
Finally, our findings that default rates are higher on complex securities and that the foreclosure rates of loan pools in more complex deals are higher are consistent with complexity being used to mask low quality collateral. Therefore, our results provide evidence of asymmetric information between security issuers and investors in the ABS market. Theoretical literature (e.g., Bhattacharya, Reny, and Spiegel (1995), Rahi (1996), Hanson and Sunderam (2013)) shows that such asymmetric information can cause trading to collapse.

Our paper is more narrowly related to a small but growing literature on security complexity. Furfine (2012) analyzes complexity and security performance in the commercial MBS (CMBS) market and finds that more complex securities perform worse. Our paper differs from his in several respects aside from the choice of asset class but the concordance of our default results and Furfine's suggests that our findings regarding complexity likely generalize to asset classes other than the one we study. Carlin, Kogan, and Lowery (2013) look at the effect of complexity on trading in a laboratory setting. Célérier and Vallée (2013) study complexity in the market for French retail structured products. Carlin (2009), Ellison and Ellison (2009), Carlin and Manso (2011), and Ellison and Wolitzky (2012) provide theoretical models of complexity.

The remainder of the paper proceeds as follows. In the next section, we describe the structure of the US RMBS market and our measures of complexity. In Section 3, we describe our dataset and the complexity we observe in the ABS market. Section 4 documents how complexity impacts security performance. In Section 5, we test whether investors understand that more complex deals are more likely to underperform and whether ratings reflect the greater risk associated with complexity. In Section 6, we discuss how well theories of security design can explain our results. Section 7 concludes.

\section{The Structure of MBS and Measuring Complexity}

The US RMBS market can be divided into two main asset classes: 1) RMBS issued by the GSEs or that use securities issued by the GSEs as collateral, and 2) RMBS issued by non-government entities that are backed by mortgages or securities not guaranteed by the GSEs. The first market is commonly known as the agency market while the second is usually referred to as the private label MBS market. In this paper we focus exclusively on the PLMBS market as agency securities are 
simpler to understand and did not see nearly the same amount of distress as the PLMBS market during the 2007-2009 crisis and its aftermath. Within the PLMBS market, we confine our attention to an asset class known as home equity ABS. Market participants use this term to refer to securities backed by residential mortgage loans including first lien loans, home equity loans, and home equity lines of credit. Securities from the typical home equity ABS deal are marketed to investors as subprime (e.g., "RES B/C") or Alt-A.

Institutions are the dominant investors in this market and the securities are extremely illiquid: Bessembinder, Maxwell, and Venkataraman (2013) find that only about one fifth of non-agency structured finance securities trade at the 21 month period beginning in May 2011. The issuers of ABS are usually large investment banks. For instance, in 2006, the peak of the ABS market, the largest three lead deal managers by issuance value were Lehman Brothers, RBS Greenwich Capital, and Goldman Sachs.

A typical ABS deal has many securities in it with a prioritization of cashflows from the underlying collateral to the top tranche (i.e., security) first, then to the second tranche, and so forth. In contrast, losses on the underlying collateral are typically applied to the lowest tranche first, then the next lowest, and so forth. Most securities within a deal are rated by multiple CRAs. The lowest tranches are usually unrated and are commonly referred to as the residual or equity piece since they behave much like equity in a firm.

Some ABS securities are used as collateral for Collateralized Debt Obligations (CDOs). As Griffin, Lowery, and Saretto (2013) argue, CDOs are even more complex than ABS. The typical ABS-backed CDO usually consists of either investment grade ABS securities or mezzanine (e.g., $\mathrm{BB}$ or residual) $\mathrm{ABS}$ securities. We do not include CDOs backed by $\mathrm{ABS}$ in our dataset for three reasons. First, CDOs backed by RMBS are a much smaller asset class than ABS. Second, getting data on these securities is far more challenging than gathering data on ABS. Bloomberg rarely has cashflows for CDOs backed by RMBS and even less frequently has prospectus supplements for these deals. Finally, as we show, there is more than enough complexity in ABS for us to understand, explain, and exploit.

ABS deals often subdivide the overall loan pool backing a deal into multiple loan groups. In a typical deal structure, a loan group primarily supports a series of senior securities but potentially with cross-collateralization from other loan groups within the same deal. For example, the issuer 
divides the loans in deal $\mathrm{ABC}$ into loan groups 1 and 2. The loans in group 1 collateralize securities AAA-1, AA-1, and A-1. Group 2 collateralizes securities AAA-2, AA-2, and A-2. If the deal has a cross-collateralization provision, in the event securities AAA-1, AA-1, and A-1 are at serious risk of default due to poor performance of the loans in group 1, cash flows from group 2 loans would be diverted to securities AAA-1, AA-1, A-1 provided that the securities group 2 collateralizes (AAA-2, AA-2, and A-2) are at little risk of default or the prepayment rate on group 2 is such that, for example, AAA-2 has been entirely paid off. Regardless of whether a multiple loan group deal has cross-collateralization, more junior tranches within the deal are typically supported by the entire loan pool (i.e., all loan groups).

\subsection{Measuring Complexity}

We measure complexity at the deal level. The idea is to proxy for the heterogeneity in the structure of a securitization and the amount of information investors and CRAs need to process in order to trade and rate these assets, respectively. For a given deal, we define the following variables: (i) the number of collateral groups (nloangroups); (ii) the number of securities or tranches (ntranches); (iii) the number of pages in the prospectus supplement (pagesprosup); (iv) the number of pages in the prospectus specifically describing the collateral (pagesmpool); and (v) the number of pages in the prospectus specifically describing the division of cashflows from the collateral to the securities in the deal (i.e., the waterfall) and details of the security more generally (pageswaterfall). All these variables are observable at issuance of the security. The results in Loughran and McDonald (forthcoming) support our use of the prospectus-based proxies for complexity.

The first two variables are self-explanatory. The portions of the prospectus supplement we use to define pagesmpool are the part of the supplement under the heading "Description of the Mortgage Pool" or a similar heading and any annex, schedule, or appendix that has tables detailing the characteristics of the loans. Some deals include tables of statistics detailing the mortgages directly in the section of the prospectus supplement labeled "Description of the Mortgage Pool" while others include these tables in an annex, schedule, or appendix. The portion of the prospectus supplement we use to define pageswaterfall is the part of the supplement under the heading "Description of the Certificates" or "Description of the Securities". Included in the waterfall are, for example, calculation of the principal and interest overcollateralization triggers and precise details regarding 
the mechanics of cross-collateralization. In defining pagesmpool and pageswaterfall, we do not include subsections of the section at the beginning of the supplement section typically headed "Summary" even if they include descriptions of the collateral or the waterfall as these subsections are less clearly demarcated than the main sections of the prospectus supplement.

While we anticipate that our complexity variables will be correlated with one another, each variable captures a different dimension of complexity. We thus construct an index of complexity, denoted by complexityindex, by extracting the first principal component across our five complexity variables at each point in time. The higher the index of complexity is, the greater the complexity of a deal. Measuring complexity using an index is also convenient because we can include in our estimation information contained in all five variables jointly without facing the issue of collinearity. The drawback of using an index is that we lose the ease of economic interpretation. In the empirical analysis, we present results using the underlying five complexity variables as well as the complexity index.

\section{Data}

We collected information on all PLMBS deals available on Bloomberg that were originated between 1999 and 2007. We restrict our attention to USD-denominated ABS backed by US assets for which Bloomberg has information on cashflows since the data quality is much higher for these securities. Our sample includes roughly half the ABS deals on Bloomberg. We manually collected all relevant information on our securities available from Bloomberg, including the prospectus supplement if it was available. All of our variables are measured at the time the security was issued except for security default and the foreclosure rate on the collateral group. Security default is a binary variable that takes a value of 1 if the security had defaulted by August 2013. The foreclosure rate on the loan group is also measured in August 2013. Our data contains variables that vary by deal, by security, and by collateral group.

Our sample starts in 1999 and ends in 2007 as the ABS market was quite small until the 2000s and there was very little issuance of ABS from 2008 onwards. ${ }^{4}$ Figure 1 illustrates the size of the market in our sample on an annual basis. Issuance peaks in 2006 at more than half a trillion USD

\footnotetext{
${ }^{4}$ Although there are a few ABS deals available on Bloomberg in the 1990s, we begin our sample in 1999 so that we can adequately control for heterogeneity in the year of issuance.
} 
and, in 2007, is less than half of what it is in 2006 both in terms of dollar volume and number of deals. Issuance is less than $\$ 100 B$ in every year before 2002 .

Most securities issued are adjustable rate and, following Ashcraft, Goldsmith-Pinkham, Hull, and Vickery (2011), we drop fixed rate securities to focus on credit risk rather than prepayment risk. However, all of our results are qualitatively the same when we include fixed rate securities in our sample.

\subsection{Deal-Level Variables}

\subsubsection{Complexity Variables}

Panel A of Table 1 summarizes our deal level variables. Although the modal deal has 2 loan groups, $12 \%$ of deals have 3 or more loan groups. The largest number of loan groups is 11 . The average number of securities per deal is 16 and one deal contains 75 separate securities.

We have prospectus supplements for $62 \%$ of the deals. We use the prospectus supplements to derive several key deal-level characteristics, including three of our complexity variables. The average number of pages in the prospectus supplement is 143 but there is substantial variation across deals: one has only 27 pages while another has almost 400 pages. Roughly 60 pages of the average prospectus supplement describe the collateral and the waterfall.

The complexity index is normalized to have a standard deviation of one for ease of interpretation. To make it easier to see the time series pattern, we normalize complexityindex to have a mean of 0 in 1999 by subtracting the mean of complexityindex in $1999 .{ }^{5}$ As Figure 2 illustrates, complexity increases over time. For example, in 1999 the average number of securities in a deal is 9 but, by 2006, it doubles to 18. Over our sample period, pagesprosup, pagesmpool, and pageswaterfall all grow by magnitudes similar to that of the number of securities. Deal size also doubles over our sample. The number of loan groups in each deal is roughly stable over time.

While we document increases in complexity over the sample period, we do not interpret increased complexity as evidence of substantial financial innovation in securitization over the 2000s. We have no evidence that any of the features of ABS deals that increase their complexity were invented

\footnotetext{
${ }^{5}$ The normalization is done at the security level as this is the unit of observation for our analysis, rather than at the deal level for which we show results in Table 2 and summary statistics in Table 1. Because of this, the standard deviation in Table 1 is not exactly one.
} 
or even diffused during the 2000s. As Foote, Gerardi, and Willen (2012) point out, markets for structured MBS had existed for a long time before the subprime boom. Riddiough and Thompson (2011) document the existence of sophisticated MBS in the US since at least the 1850s.

As Table 2 shows, the complexity variables are correlated. The highest correlation $(73 \%)$ between our complexity measures is between pagesmpool and pagesprosup. Mechanically, an increase in the number of pages required to describe the collateral increases the length of the overall supplement. There is also a high correlation $(52 \%)$ between the number of securities and the number of loan groups.

\subsubsection{Deal-Level Control Variables}

Aside from our deal-level complexity variables, we include an indicator for whether the deal provides for cross-collateralization across loan groups, the size of the deal (in millions of USD) (dealsize), the excess spread in the deal in percent (excessspread), and the volume of ABS issuance by the lead manager of the deal in the year the deal was issued (leadtot). We include deal size because Furfine (2012) uses it as a measure of complexity. We drop a small number of deals that have negative excess spread. We include the size of the issuer following He, Qian, and Strahan (forthcoming)'s finding that larger issuers received more favorable ratings. Finally, we control for the year the deal was issued since there are significant changes over time in the ABS market.

Only $30 \%$ of the deals provide for any cross-collateralization. Since more than twice that number of deals have multiple loan groups, a slight majority of deals with multiple loan groups do not provide for cross-collateralization. The average deal is for $\$ 837$ million; the smallest deal is for $\$ 25$ million and the largest deal is a 2007 deal for over $\$ 6$ billion. The average excess spread across all securities in a deal is 4.65 percentage points. The average amount of total ABS underwriting by the lead manager of the deal in the year the deal is issued is $\$ 26$ billion, with one underwriter issuing $\$ 75$ billion of ABS in a year.

We do not include deal-level overcollateralization as a control variable due to difficulties in measuring it. For example, interest-only securities are often issued with notional values such that simply summing the amount of securities issued to get the denominator for this variable is inadequate. Alternatively, for ABS backed by home equity lines of credit (HELOCs), the numerator cannot be precisely measured because the deal's collateral principal changes with time as homeowners draw 
down their credit limits.

\subsection{Security-Level Variables}

We control for the initial rating of the security. We include securities rated BBB through AAA and control for ratings using the ratings categories AAA, AA, A, and BBB. If there is a disagreement in the rating, we take the highest rating. For example, AAA takes a value of 1 if any of the three major CRAs rate the security AAA. Since there may be disagreement among the CRAs, we also include a dummy variable (disagreetranche) that takes a value of 1 if there is any disagreement among the CRAs on the rating of that tranche. The ratings disagreements are concentrated in the $\mathrm{AA}$ and A rated tranches: less than $2 \%$ of the AAA securities have a ratings disagreement, while $38 \%$ of the AA and $43 \%$ of the A rated securities have a disagreement. Only $27 \%$ of the BBB rated securities have a ratings disagreement. We experimented with controlling for subnotches and the results are quite similar. Furthermore, there appeared to be no more information in the subnotches than in the broader ratings categories we use.

Default takes a value of 1 if the security defaults by August 2013 and 0 otherwise. We define default to be an event in which the security has suffered a principal loss or in which one of the ratings agencies indicates the security is in default. For Moody's, this is a rating of Caa1 or lower. For S\&P, this is a rating of CCC+ or lower while for Fitch this is a rating of CCC or lower.

Panel B of Table 1 describes our security-level variables. We see that $36 \%$ of our securities are AAA-rated at issuance. By August 2013, 36\% of these AAA-rated securities had defaulted. By comparison, $80 \%$ of securities that had AA ratings at issuance had defaulted while $95 \%$ of securities originally rated $\mathrm{A}$ or $\mathrm{BBB}$ were in default.

We also include the subordination level of each security. Subordination is a measure of credit enhancement that measures the percentage of the value of all the securities in the deal that are below it in the priority of payments. Thus, AAA securities have the most subordination and BBB tranches have the least subordination. The mean level of subordination of a security in a deal is 12 percentage points, and the average subordination for an AAA security is 19 percentage points.

The main pricing variable in our dataset is the fixed spread the security pays above one month LIBOR. This spread is fixed for the life of the security. Actual transaction prices are extremely difficult to observe in the ABS market since, prior to May 2011, there was no requirement that 
transactions be reported to any centralized body. ${ }^{6}$ Bloomberg has transactions prices for some of our tranches on some dates, primarily the senior tranches. For dates near security issuance, the security prices are extremely close to par so that the spread is a good measure of the return investors expected to earn from investing in ABS. The mean spread on a security is 92 basis points. AAA investors were promised a mere 26 basis points while BBB investors were promised 220 basis points on average.

\subsection{Loan Group-Level Variables}

Our data contains the shares of each state in the top 5 most common property states for that pool. For example, if $25 \%$ of the loans in the pool come from California, $10 \%$ from Florida, $5 \%$ from Ohio, 3\% from Michigan, and 2\% from New York, the top 5 state shares are reported as "CA 25\%", "FL 10\%", "OH 5\%", "MI 3\%", and "NY 2\%". We do not know how the loans in a group are divided among the remaining 45 states. From the top 5 state shares, we construct the shares of the most prevalent top 5 states in the ABS market (California, Florida, New York, Illinois, and Texas). On average, $29 \%$ of the loans in a pool come from California, $9 \%$ from Florida, $4 \%$ from New York, $3 \%$ from Illinois, and $2 \%$ from Texas. We experimented with using the shares from the top 10 states and our results were quite similar.

We have detailed information on the measured ex ante quality of the collateral for less than half of the securities. Nevertheless, all of our results are quantitatively and qualitatively similar when we control for these observable collateral characteristics. The average FICO score at origination on the loans that serve as collateral for our securities is 632 and ranges from 470 to 780 . The weighted average loan-to-value (LTV) of the loans in a group has an average of $78 \%$ and a standard deviation of $13 \%$. The average share of loans in a pool that are low or no documentation is $35 \%$ with some loan groups having no reduced documentation loans and some loan groups consisting entirely of reduced documentation loans. The weighted average maturity (WAM) of the mortgages is 341 months on average and ranges from 136 to 477 months. Bloomberg has two variables that contain summary information about the principal balances of the underlying loans. These variables

\footnotetext{
${ }^{6}$ As of May 2011, the Financial Industry Regulatory Authority (FINRA) requires reporting of all MBS transactions but has not released the data it has collected for most classes of MBS, including PLMBS, to the public. FINRA has released the data from 2011 onwards to three groups of researchers; see Atanasov and Merrick (2013), Bessembinder, Maxwell, and Venkataraman (2013), and Hollifield, Neklyudov, and Spatt (2013). Bloomberg contains modeled prices for many securities but average transactions prices for far fewer securities.
} 
are the share of loans with original principal balances under $\$ 300,000$ and the share of loans with original principal balances of $\$ 300,000$ to $\$ 600,000$.

For robustness, we consider whether our results are driven by the presence of the GSEs in the ABS market. Although none of our securities are issued by the GSEs, the GSEs bought substantial quantities of AAA ABS. Often, one loan group in a multiple loan group deal is tailored for one of the GSEs. The GSEs invested in AAA ABS backed by loan groups that consisted entirely of loans with principal balances that conform to their conforming loan limit. We can frequently identify such cases from the collateral group description Bloomberg provides. We create a variable called conforming that takes a value of 1 if the collateral group description contains terms such as "CONF", "CON", or "CONFORMING". The variable conforming takes a value of 0 if the collateral group description contains terms such as "NCONF", "NCON", or "NONCONFORMING". We manually code the exact collateral descriptions as conforming to prevent misclassification. If the collateral group description does not indicate whether the loans are conforming or non-conforming, conforming is missing.

\section{Security Performance and Complexity}

We define $D_{i, t+T}$ to be a variable that equals one if security $i$ issued at $t$ has defaulted in our sample period, and zero otherwise. We model the probability of default using a probit

$$
P\left(D_{i, t+T}=1\right)=\Phi\left(\text { Complex }_{i, j, t}^{\prime} \beta_{1}+\text { Controls }_{i, j, t}^{\prime} \beta_{2}\right) .
$$

where $\Phi()$ is the cumulative standard normal distribution and Complex $x_{i, j, t}$ is a vector of complexity variables for security $i$ in deal $j$ known at issuance of the security. A set of control variables, collected in the vector Controls $s_{i, j, t}$, is observable at issuance of security $i$. The benchmark set of controls includes the deal size (dealsize), an indicator for cross-collateralization in the deal (crosscollat), the amount of excess spread in the deal (excessspread), the issuance volume of the lead manager in the year the deal was issued (leadtot), dummies for the year of issuance, controls for the geography of the collateral, dummies for the rating categories, the percentage subordination of the security (subordination), the spread above one month LIBOR the security promises (spread), and a dummy variable indicating whether the CRAs disagreed on the security's rating at issuance 
(disagreetranche). We include disagreetranche to capture the possibility that, for example, some investors treat what we code an AA security as an A security.

Table 3 contains the results from estimating various specifications of equation (1). The table presents marginal effects from the probit estimates to facilitate understanding the economic magnitudes. As Columns 1 through 5 illustrate, all of our measures of complexity predict security default. The effects are statistically significant at the $1 \%$ level. The signs of the prospectus-based measures indicate that longer prospectus supplements, or particular portions thereof, predict more default. Although longer prospectus supplements could in principle indicate more transparency, more transparency is unlikely to be associated with more default. Rather, our results suggest that longer prospectus supplements are associated with decreased readability (or less transparency) consistent with the findings of Loughran and McDonald (forthcoming).

The effect of complexity on default is also economically important. The addition of one loan group increases the likelihood that a security will default by 3 percentage points. An increase of one standard deviation in the number of securities in a deal (6 securities) raises the likelihood that a security will default by one and a half percentage points. An increase in the prospectus length of 38 pages ( 1 standard deviation) increases the risk of default by 2.5 percentage points. An increase of 18 pages in the length of the portion of the prospectus devoted to describing the collateral raises the chance of default by 1.5 percentage points as does a one standard deviation ( 9 page) increase in the length of the portion of the prospectus that describes the waterfall.

Columns 6 and 7 of Table 3 present the effects of complexity when we combine our complexity variables. In Column 6, we include all 5 measures of complexity simultaneously without regard to potential collinearity. The number of securities in the deal and the number of pages used to describe the collateral are not significant predictors of default once we control for other dimensions of complexity. Although, not surprisingly, the magnitudes of the effects decrease, nloangroups, pagesprosup, and pageswaterfall continue to be statistically significant predictors of default at the $1 \%$ level.

In Column 7, we present our results from combining all complexity variables using their first principal component, complexityindex. The standard deviation of complexityindex is 1 and the interpretation of its marginal effect is that a one standard deviation increase in the overall complexity of the deal raises the risk of default by 3 percentage points. 
As Table 4 shows, the relation between default and complexity is stronger for AAA securities than for all securities. In Table 4, we perform the same analysis as we do in Table 3 but including only AAA securities. For AAA securities, adding one loan group to a deal is associated with a 6 percentage point increase in the likelihood of default rather than the 3 percentage point increase we observed in our benchmark model. Issuing one more security from a deal results in a 37 basis point increase in the risk of default for AAA securities while for all securities the increase in the chance of default from one more security is only 26 basis points. We also see stronger relations between default and pagesprosup, pagesmpool, and pageswaterfall for AAA securities than for all securities.

Not only are the absolute magnitudes larger for AAA securities, the percentage increases in default are larger. More than $80 \%$ of securities rated below AAA default while only $36 \%$ of AAA securities default so that a given percentage point increase in the risk of default is a much larger percent change for AAA securities. As Column 8 shows, a one unit increase in complexityindex raises the likelihood of default by 7 percentage points for securities initially rated AAA. As only $36 \%$ of our AAA securities default, a one unit increase in complexity raises the risk of default by $19 \%$ for AAA securities.

Not surprisingly, AAA securities default the least and AA securities default the second least. Securities initially rated A do not default statistically less frequently than BBB securities. However, several variables beyond ratings predict default. Importantly, spreads on individual securities are highly predictive of default even after controlling for their rating, implying that investors priced securities using information beyond the rating. A 100 basis point increase in the spread is associated with a 2.5 percentage point greater risk of default. Furthermore, Table 4 shows that even AAA investors priced riskier securities higher. Adelino (2009) also finds that spreads on MBS contain information about the risk of the security beyond what the information encapsulated in the rating. We also see that more credit support in the form of subordination reduces the risk of default. A one percentage point increase in the level of subordination decreases the risk of default by approximately half a percentage point. Larger deals and deals from larger underwriters also default more often. 


\subsection{Sensitivity Analysis}

We conduct several sensitivity analyses of our results to our model specification. Table 5 presents the key alternative specifications using the summary variable complexityindex; the full results for the individual complexity variables are available from the authors upon request. Column 1 of Table 5 reproduces our benchmark specification with complexityindex (Column 8 of Table 3).

Columns 2 and 3 of Table 5 show that, although complexity is a stronger predictor of default for AAA securities, it is also an economically important predictor of default for securities not rated AAA. For securities not rated AAA, a one standard deviation increase in complexity is associated with a 1.3 percentage point rise in the likelihood of default; the coefficient on default is statistically significant at the $1 \%$ level. We estimated the effect of complexity on securities in each rating category separately (results not shown) and found that the relation between complexity and default is similar for AA, A, and BBB securities.

In Column 4, we cluster the standard errors at the deal level. Since several of our variables are security-level while other variables, including our complexity variables, are deal-level and still others are loan group-level, the correct clustering of the standard errors, if any, is unclear. Nevertheless, the effect of complexity on default continues to be statistically significant at the $1 \%$ level when we cluster at the deal level. However, when we cluster the standard errors by deal, dealsize is significant at the $5 \%$ level and the coefficient on leadtot is no longer significant at a conventional level.

In Column 5, we present the results from estimating equation (1) when we include additional summary characteristics about the loans as control variables. The specification in Column 5 adds the weighted average LTV at origination (ltv), the average FICO score on the loans (fico), the share of loans that are no or low documentation (lownodocshare), the share of loans with balances under $\$ 300,000$, the share of loans with balances of $\$ 300,000$ to $\$ 600,000$, and the weighted average maturity (wam) of the loans to the vector of controls. All of these variables are available for only about half the securities and, as such, the specification in Column 5 cuts our sample in half. The coefficient on complexityindex continues to be statistically significant at the $1 \%$ level although its magnitude falls by about one third. Likely as a result of the much smaller sample, the coefficient on dealsize is significant at only the $10 \%$ level and the coefficient on crosscollat and leadtot are no 
longer statistically significant when we include collateral quality controls.

Column 6 contains the results from estimating equation (1) excluding securities collateralized primarily by pools of entirely conforming pools, i.e., those pools for which conforming=1. Our motivation for the specification in Column 6 is that the GSEs had a substantial demand for PLMBS and usually only purchased securities based on conforming pools (see Ghent, Hernández-Murillo, and Owyang (2013)). Deals in which the GSEs bought a security might thus have almost mechanically had one more loan group which might in turn have increased measured complexity along other dimensions. One concern then is that our complexity variables are only picking up the influence of the GSEs. However, our results are extremely similar when we include securities collateralized primarily by pools that the collateral group description describes as conforming.

In Column 7, we include our additional collateral quality controls, exclude securities based on conforming pools, and cluster the standard errors by deal. When we combine all these robustness exercises, it continues to be the case that an increase in complexityindex raises the risk of default and that the effect is significant at the $1 \%$ level.

In another sensitivity exercise, we consider whether the results are sensitive to our way of controlling for the geography of the loan group. In particular, we estimate a specification in which, rather than controlling for the top 5 state shares, we control for the geographic concentration of the loan group. We measure the concentration of the loan group using a Herfindahl-Hirschmann Index (HHI) of the top five states in each loan group. The coefficients on our complexity variables are very similar to those in our other specifications. The results are available from the authors upon request.

Finally, we conduct our analysis using discrete measures of complexity to ensure the robustness of our results to outliers. For example, rather than including the number of loan groups itself as in Column 1 of Table 3, we include two dummy variables for the number of loan groups, nloangroups2 and nloangroups3ormore. Similarly, rather than using the number of tranches as in Column 2 of Table 3, we include a dummy variable that takes a value of 1 if the number of securities in the deal was above the median and 0 otherwise. We construct parallel discrete measures of complexity for the number of pages in the prospectus supplement, the number of pages required to describe the collateral, the number of pages required to describe the waterfall, and the number of disagreements in the deal. The results from using these discretized complexity measures also imply that the risk 
that a security will default increases with its complexity. The results using discretized complexity measures are available from the authors upon request.

\section{The Pricing and Rating of Complexity}

\subsection{Investors}

Given that complex deals perform worse ex post, it is important to see how investors price complexity ex ante to ascertain whether they were aware that more complex securities were more likely to perform poorly. We analyze the pricing of complexity by regressing the yield spread of securities on various determinants. More specifically, let $Y_{i}$ be the yield of security $i$ at issuance in excess of one month LIBOR. Our goal is to see whether more complex securities, as measured by our complexity variables, had higher yields.

We run the following cross-sectional regression

$$
Y_{i}=\text { Complex }_{i, j}^{\prime} \gamma_{1}+\text { Controls }_{i, j}^{\prime} \gamma_{2}+\varepsilon_{i}
$$

where, as before, Complex $x_{i, j}$ is a vector of complexity variables for security $i$ in deal $j$ and Controls $s_{i, j}$, are control variables, observable at origination of security $i$, and $j$ indexes either the deal or the group.

Table 6 presents the results from estimating equation (2). Most of the complexity variables have negative coefficients implying that investors accepted lower returns for worse performance. Furthermore, the coefficients are often statistically significant at the $1 \%$ level including for our summary complexity measure. The magnitudes are small, however: a one standard deviation in complexityindex is associated with a reduction in spreads of only 1 basis point. Overall, the results indicate that investors did not perceive more complex securities to be of lower quality ex ante.

As expected, AAA investors accepted lower rates of return than AA, A, or BBB investors, and AA investors were promised lower returns than A or BBB investors. Investors perceived larger deals to be less risky as well as deals in which there was more excess spread.

We perform the same sensitivity analyses for our examination of spreads and complexity as we did for default (see Table 5 for some examples). The results are available from the authors upon 
request.

\subsection{Credit Rating Agencies}

It is also useful to test whether the CRAs rated securities from more complex deals to reflect their higher likelihood of default. It is indeed possible that the CRAs, which should have analyzed all the intricate details of the deal and security structure, understood these securities would likely perform worse and required issuers to provide more support for the senior tranches to be rated AAA in more complex deals.

The nature of the ratings process in the ABS market is not for issuers to prepare a set of securities and then solicit a rating. Rather, the institutional structure of the ABS market consists of a dialogue between the issuer and the CRA prior to security issuance. In essence, the issuer asks the CRA how it requires the issuer to structure the security for the CRA to give it a particular rating. One main provision consists of how much of the deal can be rated AAA. Limiting the portion of the deal rated AAA is equivalent to requiring more subordination for each AAA security in the deal.

If the observed subordination measures are unbiased measures of required credit support, we expect that more complex deals will have more subordination to compensate for their higher risk. However, several recent papers have analyzed equilibria in which disclosed ratings are systematically biased. Skreta and Veldkamp (2009) show that if issuers engage in ratings shopping, observed ratings will be systematically biased upward as the securities get more complex. ${ }^{7}$ If issuers shop for ratings and the deal gets structured according to the requirements of the most favorable CRA, observed subordination levels may not be unbiased measures of credit quality.

Even if issuers do not explicitly shop for ratings, complexity may increase ratings inflation if CRAs cater to issuers to gain their business or to institutional investors' regulatory requirements. ${ }^{8}$ The model of Opp, Opp, and Harris (2013) predicts more ratings inflation as the complexity of

\footnotetext{
${ }^{7}$ Technically, Skreta and Veldkamp's model predicts a non-monotonic relationship between observed ratings and security complexity. Beyond a certain level of complexity, ratings are too noisy to be valuable signals and, as investor demand for ratings decreases, rating shopping falls. However, Skreta and Veldkamp's model does not contain a regulatory motive for ratings. Given a regulatory motive for ratings (see, e.g., Bongaerts, Cremers, and Goetzmann (2012), Stanton and Wallace (2012), or Opp, Opp, and Harris (2013)), we are likely to be in the case where complexity increases shopping.

${ }^{8}$ See Griffin, Nickerson, and Tang (2013) for a discussion of the distinction between explicit rating shopping and rating catering.
} 
the asset increases because of catering to regulatory requirements. Even without a regulatory requirement, complexity may increase the cost of accurately rating an investment and decrease the likelihood that investors will discover the ratings inflation. If CRAs compete for business, as Bolton, Freixas, and Shapiro (2012) model them, greater complexity may indeed increase the incentive to inflate ratings. Such ratings inflation may require CRAs to adjust their models, unlike rating shopping. Griffin and Tang (2012) find that CRAs did, in fact, make such adjustments during the MBS boom of the 2000s. The literature on CRAs' incentives and biased ratings, while not the focus of this paper, is nevertheless relevant in helping us understand the connection between ratings' accuracy and deal complexity.

To test whether the CRAs gave less favorable ratings to more complex deals, we estimate

$$
\text { subordination }_{i}=\text { Complex }_{i, j}^{\prime} \gamma_{1}+\text { Controls }_{i, j}^{\prime} \gamma_{2}+u_{i}
$$

where Complex $_{i, j}$ is a vector of complexity variables for security $i$ in deal $j$ and Controls $s_{i, j}$, are control variables, observable at origination of security $i$, and $j$ indexes either the deal or the group. In the absence of explicit rating shopping or rating catering, we anticipate $\gamma_{1}>0$ given the higher default risk of more complex deals. In estimating equation (3), we restrict our attention to AAA securities.

Table 7 presents the results. Although the effects of complexity on subordination are less consistent across the complexity variables than the effect of complexity on default that we present in Table 3, the coefficients are negative and statistically significant or else statistically insignificant when we include each complexity variable individually. Our summary complexity measure, complexityindex, is highly statistically significant. A one standard deviation increase in complexityindex is associated with 34 basis points less subordination. As $\gamma_{1}$ is negative and statistically significant, we reject the hypothesis that credit ratings are unbiased, accurate measures of complex securities' quality.

Increasing the number of loan groups is particularly strongly related to lower levels of subordination. Adding one more loan group results in 50 basis points less subordination; the coefficient is statistically significant at the $1 \%$ level both when we include only the number of loan groups and when we include all our complexity measures simultaneously. 
We perform several sensitivity analyses on the results from Table 7 . Table 8 reports the results from selected sensitivity analyses. In Columns 2 and 4, we report the results when we exclude securities collateralized by conforming pools. We report these particular specifications because the effect of complexity on subordination is especially strongly related to the number of loan groups. The number of loan groups in turn is partly driven by the GSEs' demand for securities based on conforming pools. Thus, it is important to understand whether complexity affects ratings only because it is associated with deals in which one or both of the GSEs bought an AAA security. As Columns 2 and 4 illustrate, our results are nearly identical when we exclude conforming pools. As Column 5 shows, the effect of complexity on subordination continues to be statistically significant at the $10 \%$ level when we cluster the standard errors at the deal level. Finally, in Column 6 , we include securities initially rated AA along with our AAA securities.

We also investigate whether the ratings inflation is in the senior AAAs (sometimes called supersenior AAAs) or is confined to the junior support AAAs. We identify the senior AAAs as follows: for each collateral group, we take the AAA security with the lowest spread to LIBOR as the senior AAA. The precise way these securities have higher priority is likely in the fine details of the waterfall. Roughly half of our AAAs are senior according to our definition. When we estimate equation (3) for only the senior AAAs, the coefficient on complexityindex indicates that a one standard deviation increase in complexity only lowered subordination by 16 basis points and the coefficient is not statistically significant. In contrast, when we estimate equation (3) for AAAs that are not senior, we find that a one standard deviation increase in complexity is associated with 60 basis points less subordination and the coefficient is significant at the $1 \%$ level. As such, the ratings inflation is primarily in the more junior AAAs. These results are available upon request. ${ }^{9}$

Overall, the results demonstrate that in more complex deals, the CRAs gave AAA ratings to securities with less credit support. This finding is consistent with explicit rating shopping and rating catering. Without the details of the CRAs' rating models, we cannot distinguish between shopping and catering, nor can we decisively eliminate the possibility that the CRAs were confused by the more complex deals. Nevertheless, the CRAs clearly exacerbated the problems with complexity.

\footnotetext{
${ }^{9}$ We also estimated our default and pricing regressions with the rating categories AAA_senior, AAA_notsenior, $\mathrm{AA}, \mathrm{A}$, and $\mathrm{BBB}$ rather than $\mathrm{AAA}, \mathrm{AA}, \mathrm{A}$, and $\mathrm{BBB}$ as in our benchmark specification. All of our results for default and spreads are qualitatively the same when we use these finer rating categories. The magnitude of the relationship between complexity and default is slightly larger when we use AAA_senior, AAA_notsenior, AA, A, and BBB as the rating categories.
} 
Although we find that complexity leads to more generous ratings, ratings inflation does not explain the default results we find in Section 4. In all of our default specifications, we control for both the level of subordination and the rating of the security. If we omit the level of subordination from the default regressions, the effect of complexity on default is even larger because it captures both the direct effect of complexity on default and the indirect level of complexity on subordination.

The results in Tables 7 and 8 also indicate that larger deals and deals from larger issuers were treated more generously by CRAs. Our finding that larger issuers received more inflated ratings is consistent with the findings of He, Qian, and Strahan (forthcoming).

\section{Complexity in the MBS Market and Security Design}

We have shown that more complex securities perform worse and that investors did not price more complex securities in a manner consistent with their perceiving them to be riskier. Furthermore, we have not found evidence that the CRAs understood that more complex securities were riskier. From the perspective of investors, complexity thus appears to be confusing rather than welfare-enhancing.

Can we reconcile our results with theories of security design? In this section, we consider how well different theories of security design explain the level of complexity we observe in the MBS market and the facts about complexity that we have documented. We evaluate the consistency of our results with two classic theories, "tailoring theory" and "information sensitivity theory".

Allen and Gale's (1988) seminal theory of complexity, which we term tailoring theory, posits that complexity arises to complete the market in the Arrow-Debreu sense. In tailoring theory, an issuer (a trust in our case) should offer many different types of securities collateralized by the same assets (a pool of mortgages in our case) that satisfy different investor appetites. In so doing, investors maximize the revenue the issuer receives from the sale of the securities because each security is held by the investor that values it most. ${ }^{10}$

The tailoring theory of complexity is consistent with the existence of loan groups structured specifically to satisfy the GSEs' demand. However, for the tailoring theory to explain the substantial complexity that we document, the different loan groups within deals would have to be dissimilar to

\footnotetext{
${ }^{10}$ Allen and Gale (1991) extend their completing the market argument to a market model with short sales. In general, investors cannot short ABS. Since 2006, investors can short indices of ABS via the ABX. However, in their analysis of the ABX, Stanton and Wallace (2011) find that it poorly reflects the performance of the assets underlying it prior to 2011 .
} 
one another. That is, the collateral must be customized within a deal to satisfy particular clients' requests for specific types of collateral resulting in substantively dissimilar loan groups within a deal. If the loan groups are quite similar to one another, spanning different states of the world cannot be the main reason for the different loan groups since investors within a deal are buying assets backed by effectively the same collateral.

If groups within a deal are designed to cater to different risk appetites or preferences for particular types of collateral, then the loan characteristics across groups within the same deal must be different. To understand how different the loan characteristics are, we compare them to the loan characteristics across deals. In the absence of tailoring, we expect the two measures to be roughly equal. We compute the mean absolute deviation (MAD) of several loan characteristics between groups within a deal and across deals. That is, for each loan characteristic $c$, we compute

$$
\operatorname{DiffIntra}^{c}=\frac{1}{N} \sum_{k=1}^{N}\left|\operatorname{Char}_{k, j}^{c}-\frac{1}{N_{j}} \sum_{n=1}^{N_{j}} \operatorname{Char}_{k, j}^{c}\right|
$$

and

$$
\operatorname{DiffInter}^{c}=\frac{1}{N} \sum_{k=1}^{N}\left|\operatorname{Char}_{k, j}^{c}-\frac{1}{N_{T}} \sum_{l=1}^{N_{T}} \operatorname{Char}_{l, j}^{c}\right|
$$

where $N$ is the total number of loan groups in our data, $N_{T}$ is the total number of loan groups in year $\mathrm{T}$, and $N_{j}$ is the total number of loan groups in deal $j$. If the division into loan groups is because of tailoring, we expect DiffIntra ${ }^{c}>\operatorname{DiffInter}^{c}$.

Table 9 compares the differences between loan groups within deals and the differences between loan groups across deals. We see that there is much more variation in loan characteristics across deals than within them. The largest amount of variation in loan group characteristics within deals is in the original principal balances. The intra-deal differences in principal balances are likely due to the influence of the GSEs and, even along this dimension, there is greater variation across deals than within deals. Thus, tailoring cannot explain a substantial portion of the complexity creating by subdividing the loan pool into separate loan groups. ${ }^{11}$

\footnotetext{
${ }^{11}$ Furthermore, the Allen and Gale theory of complexity is somewhat difficult to apply to the RMBS market since, unlike a corporation, the underlying assets in a trust that issues mortgage-backed securities are inherently more divisible than a corporation. Should an RMBS consist of 1000 loans or 5000 loans? Some pooling of loans can be explained by diversification benefits (DeMarzo, 2005) and the desire to overcome adverse selection created by the originator of the loans (not necessarily of the securities) having more information than investors (Riddiough (1997) and DeMarzo (2005)). Without additional theory, however, it is difficult to understand why so many securities are
} 
Another strand of the literature, pioneered by Gorton and Pennacchi (1990) and Boot and Thakor (1993), posits that the multiple securities we observe can be explained by the need for some securities to be informationally insensitive or at least less informationally sensitive. In Gorton and Pennacchi, the exploitation of uninformed traders by informed traders creates a need for some securities to be less informationally sensitive. By creating less informationally sensitive securities, the issuer expands the potential market for its securities to those investors that are either unable or unwilling to acquire information about the quality of the assets. In Boot and Thakor, an issuer divides its cash flows into multiple claims with some securities (i.e., equity) being more information-sensitive than others; the creation of multiple securities from a single asset arises to incentivize information acquisition.

Consistent with the theory of information sensitivity, ABS deals include both informationally sensitive securities (i.e., securities with ratings below AAA) and less informationally less sensitive securities (i.e., securities with AAA ratings). Unfortunately, the information sensitivity model does not provide a prediction as to how many different securities an asset should collateralize, only that there should be differences in the information sensitivity of the securities that are issued. What is difficult to understand is why it is necessary to have so many different informationally sensitive and informationally insensitive securities within the same deal. The average deal has 16 securities.

Three other aspects of complexity cannot be explained by either the tailoring theory or the information acquisition theory of security design. First, neither theory can explain why securities from more complex deals default more. Furthermore, neither theory predicts that securities from more complex deals should receive more inflated ratings. Finally, as Table 10 shows, more complex deals are associated with lower quality collateral as measured by the ex post foreclosure rate.

In Table 10, we regress the foreclosure rate of the loan group on all observable collateral characteristics in our dataset and our deal complexity variables. When the complexity variables enter individually, all the signs on the complexity variables are positive. The coefficients on pagesprosup, pagesmpool, and pageswaterfall are statistically significant. In Column 8, we include our summary measure of complexity, complexityindex. The coefficient on complexityindex indicates that a one

issued within one deal rather than issued from separate deals. It is possible that there is some high fixed cost of issuing a deal such that it is advantageous to issue very large deals with more securities and loan groups rather than put the different loan groups into separate deals. Certainly, it seems likely that there are costs to establishing a trust (e.g., legal fees) that are not present with subdividing loans within a deal. However, it is unclear what puts an upper bound on the number of loans within a pool if the fixed costs are very high. 
standard deviation increase in complexity is associated with a 40 basis point increase in the foreclosure rate in a pool. The coefficient on complexityindex is significant at the $5 \%$ level. Because we control for the year of issuance of the deal, the relation between complexity and collateral quality that we uncover is not being driven by the fact that, over our sample period, complexity is increasing (see Figure 2) while collateral quality is decreasing.

In summary, several facts we uncover about complexity are difficult to reconcile with traditional theories of security design including those that allow explicitly for informational asymmetry between the issuer of a security and investors. Our results suggest that issuers may have an informational advantage over investors in this market and that they use complexity to exploit this informational advantage. The most closely related work is in industrial organization models wherein firms can obfuscate prices to retain clients (see Ellison and Ellison (2009), Carlin (2009), and Ellison and Wolitzky (2012)). Carlin and Manso (2011) embed such strategic obfuscation into a model of mutual funds.

\section{Conclusion}

In this paper, we propose measures of complexity for securitized assets. Our measures are designed with the RMBS market in mind. We apply our measures to the ABS market and document an increase in complexity in the 2000s. We then show that more complexity is robustly associated with a higher likelihood of default and that the increase in the risk of default associated with complexity is greatest for securities designed to be informationally insensitive. Ex ante pricing indicates that investors did not think more complex securities would default more although several aspects of MBS risk beyond credit ratings were priced. The CRAs rated more complex deals more liberally indicating that they failed to distill the complexity of these deals into the rating. Our results are consistent with the market for PLMBS being subject to strategic obfuscation during the subprime boom.

\section{References}

Adelino, Manuel, 2009. Do Investors Rely Only on Ratings? The Case of Mortgage-Backed Securities. Manuscript, Duke University. 
Allen, Franklin, and Douglas Gale, 1988. Optimal Security Design. Review of Financial Studies, 1:3, 229-63.

Allen, Franklin and Douglas Gale, 1991. Arbitrage, Short Sales, and Financial Innovation. Econometrica, 59:4, 1041-68.

Ashcraft, Adam, Paul Goldsmith-Pinkham, Peter Hull, and James Vickery, 2011. Credit Ratings and Security Prices in the Subprime MBS Market. American Economic Review: Papers and Proceedings, 101:3, 115-9.

Atanasov, Vladimir and John J. Merrick Jr., 2013. The Effects of Market Frictions on Asset Prices: Evidence from Agency MBS. Manuscript, College of William and Mary.

Barber, Brad M. and Terrance Odean, 2008. All That Glitters: The Effect of Attention and News on the Buying Behavior of Individual and Institutional Investors. Review of Financial Studies, $21: 2,785-818$.

Barberis, Nicholas and Richard Thaler, 2003. A Survey of Behavioral Finance. Ch. 18 in Handbook of the Economics of Finance, Volume 1 Part B, George M. Constantinides, Milton Harris, and René M. Stulz, eds. Elsevier.

Bessembinder, Hendrik, William Maxwell, and Kumar Venkataraman, 2013. Introducing Daylight to Structured Credit Products. Financial Analysts Journal, 69:6, 55-67.

Bhattacharya, Utpal, Philip J. Reny, and Matthew Spiegel, 1995. Destructive Interference in an Imperfectly Competitive Multi-Security Market. Journal of Economic Theory, 65, 136-70.

Bolton, Patrick, Xavier Freixas, and Joel Shapiro, 2012. The Credit Ratings Game. Journal of Finance, 67:1, 85-111. 
Bongaerts, Dion, K.J. Martijn Cremers, and William N. Goetzmann, 2012. Tiebreaker: Certification and Multiple Credit Ratings. Journal of Finance, 67:1, 113-52,

Boot, Arnoud W.A. and Anjan V. Thakor, 1993. Security Design. Journal of Finance, 48:4, 1349-78.

Carlin, Bruce Ian, 2009. Strategic Price Complexity in Retail Financial Markets. Journal of Financial Economics, 91, 278-87.

Carlin, Bruce Ian, Shimon Kogan, and Richard Lowery, 2013. Trading Complex Assets. Journal of Finance, 68:5, 1937-60.

Carlin, Bruce Ian and Gustavo Manso, 2011. Obfuscation, Learning, and the Evolution of Investor Sophistication. Review of Financial Studies, 24:3, 754-85.

Célérier, Claire and Boris Vallée, 2013. What Drives Complexity? A Look into the Retail Market for Structured Products. Manuscript, University of Zurich.

Cheng, Ing-Haw, Sahil Raina, and Wei Xiong, 2013. Wall Street and the Housing Bubble. Manuscript, Princeton University.

Cohen, Lauren and Andrea Frazzini, 2008. Economic Links and Predictable Returns. Journal of Finance. 63:4, 1977-2011.

Cohen, Lauren and Dong Lou, 2012. Complicated Firms. Journal of Financial Economics, 104, 383-400.

DellaVigna, Stefano and Joshua M. Pollet, 2007. Demographics and Industry Returns. American Economic Review, 97:5, 1667-1702. 
DellaVigna, Stefano and Joshua M. Pollet, 2009. Investor Inattention and Friday Earnings Announcements. Journal of Finance, 64:2, 709-49.

DeMarzo, Peter M., 2005. The Pooling and Tranching of Securities: A Model of Informed Intermediation. Review of Financial Studies, 18:1, 1-35.

Duffie, Darrell and Rohit Rahi, 1995. Financial Market Innovation and Security Design: An Introduction. Journal of Economic Theory, 65, 1-42.

Ellison, Glenn and Sara Fisher Ellison, 2009. Search, Obfuscation, and Price Elasticities on the Internet. Econometrica, 77:2, 427-52.

Ellison, Glenn and Alexander Wolitzky, 2012. A Search Cost Model of Obfuscation. RAND Journal of Economics, 43:3, 417-41.

Foote, Christopher L., Kristopher S. Gerardi, and Paul S. Willen, 2012. Why Did So Many People Make So Many Ex Post Bad Decisions? The Causes of the Foreclosure Crisis. Federal Reserve Bank of Boston Working Paper No. 12-2.

Furfine, Craig, 2012. Complexity as a Means to Distract: Evidence from the Securitization of Commercial Mortgages. Manuscript, Northwestern University.

Gale, Douglas, 1992. Standard Securities. Review of Economic Studies, 59:4, 731-55.

Gennaioli, Nicola, Andrei Shleifer, and Robert Vishny, 2012. Neglected Risks, Financial Innovation, and Financial Fragility. Journal of Financial Economics, 104, 452-68.

Ghent, Andra C., Rubén Hernández-Murillo, and Michael T. Owyang, 2013. Did Affordable Housing Legislation Contribute to the Subprime Securities Boom? Manuscript, Arizona State Uni- 
versity.

Gorton, Gary and George Pennacchi, 1990. Financial Intermediaries and Liquidity Creation. Journal of Finance, 45:1, 49-71.

Griffin, John M., Richard Lowery, and Alessio Saretto, 2013. Complex Securities and Underwriter Reputation: Do Reputable Underwriters Produce Better Securities? Manuscript, University of Texas (Austin).

Griffin, John M., Jordan Nickerson, and Dragon Yongjun Tang, 2013. Rating Shopping or Catering? An Examination of the Response to Competitive Pressure for CDO Credit Ratings. Review of Financial Studies, 26:9, 2270-310.

Griffin, John M. and Dragon Hongjun Tang, 2012. Did Subjectivity Play a Role in CDO Credit Ratings? Journal of Finance, 67:4, 1293-1328.

Hanson, Samuel G. and Adi Sunderam, 2013. Are there too Many Safe Securities? Securitization and the Incentives for Information Production. Journal of Financial Economics, 108, 565-84.

He, Jie (Jack), Jun 'QJ' Qian, and Philip E. Strahan, forthcoming. Are All Ratings Created Equal? The Impact of Issuer Size on the Pricing of Mortgage-Backed Securities. Journal of Finance.

Hirshleifer, David and Siew Hong Teoh, 2003. Limited Attention, Information Disclosure, and Financial Reporting. Journal of Accounting and Economics, 36, 337-86.

Hirshleifer, David, Sonya S. Lim, and Siew Hong Teoh, 2009. Driven to Distraction: Extraneous Events and Underreaction to Earnings News. Journal of Finance, 64, 2289-2325.

Hollifield, Burton, Artem Neklyudov, and Chester Spatt, 2013. Bid-Ask Spreads and the Pricing of Securitizations: 144a vs. Registered Securitizations. Manuscript, Carnegie Mellon University. 
Hong, Harrison and Jeremy C. Stein, 1999. A Unified Theory of Underreaction, Momentum Trading, and Overreaction in Asset Markets. Journal of Finance, 54:6, 2143-84.

Hong, Harrison, Walter Torous, and Rossen Valkanov, 2007. Do Industries Lead Stock Markets? Journal of Financial Economics, 83, 367-96.

Hou, Kewei, 2007. Industry Information Diffusion and the Lead-lag Effect in Stock Returns. Review of Financial Studies, 20:4, 1113-1138.

Huberman, Gur and Tomer Regev, 2001. Contagious Speculation and a Cure for Cancer: A Nonevent that Made Stock Prices Soar. Journal of Finance, 55:1, 387-96.

Loughran, Tim and Bill McDonald, forthcoming. Measuring Readability in Financial Disclosures. Journal of Finance.

Menzly, Lior and Oguzhan Ozbas, 2010. Market Segmentation and Cross-Predictability of Returns. Journal of Finance, 65:4, 1555-80.

Merton, Robert C., 1987. A Simple Model of Capital Market Equilibrium with Incomplete Information. Journal of Finance, 42:3, 483-510.

Opp, Christian C., Marcus M. Opp, and Milton Harris, 2013. Rating Agencies in the Face of Regulation. Journal of Financial Economics, 108, 46-61.

Rahi, Rohit, 1996. Adverse Selection and Security Design. Review of Economic Studies, 63:2, 287-300.

Riddiough, Timothy J., 1997. Optimal Security Design and Governance of Asset-Backed Securities. Journal of Financial Intermediation, 6, 121-52. 
Riddiough, Timothy J. and Howard E. Thompson, 2011. Déjà Vu All Over Again: Agency, Uncertainty, Leverage and the Panic of 1857. Manuscript, University of Wisconsin (Madison).

Sims, Christopher A., 2003. Implications of Rational Inattention. Journal of Monetary Economics, 50, 665-90.

Skreta, Vasiliki and Laura Veldkamp, 2009. Ratings Shopping and Asset Complexity: A Theory of Ratings Inflation. Journal of Monetary Economics, 56, 678-95.

Stanton, Richard and Nancy Wallace, 2011. The Bear's Lair: Index Credit Default Swaps and the Subprime Mortgage Crisis. Review of Financial Studies, 24:10, 3250-80.

Stanton, Richard and Nancy Wallace, 2012. CMBS Subordination, Ratings Inflation, and Regulatory-Capital Arbitrage. Manuscript, University of California (Berkeley). 
Figure 1: US Private-Label Home Equity ABS Issuance by Year, 1999-2007

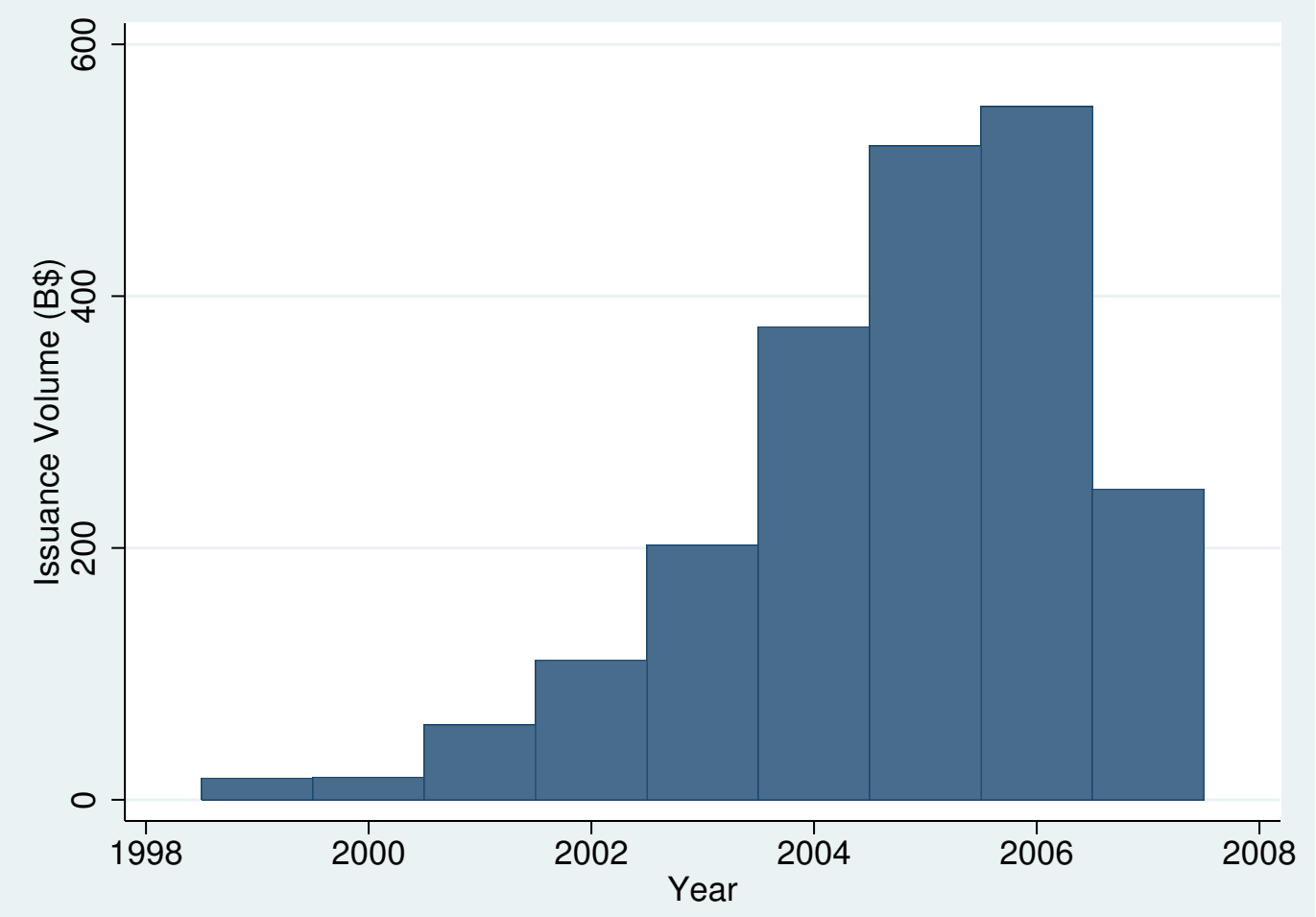

Includes all deals with detailed data available via Bloomberg terminals. 
Figure 2: Means of Deal Size and Complexity Variables by Year, 1999-2007

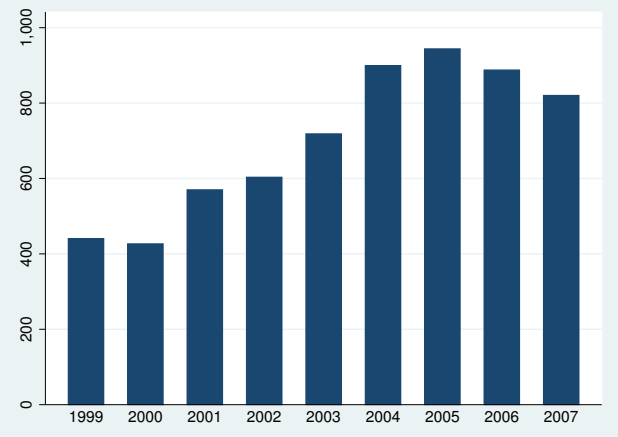

(a) Deal Size $(\$ M)$

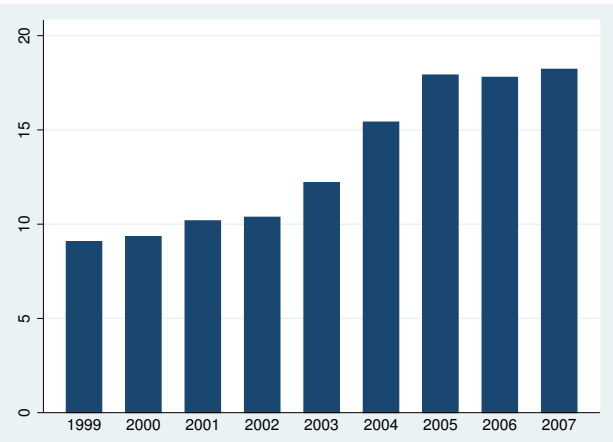

(c) No. of Securities

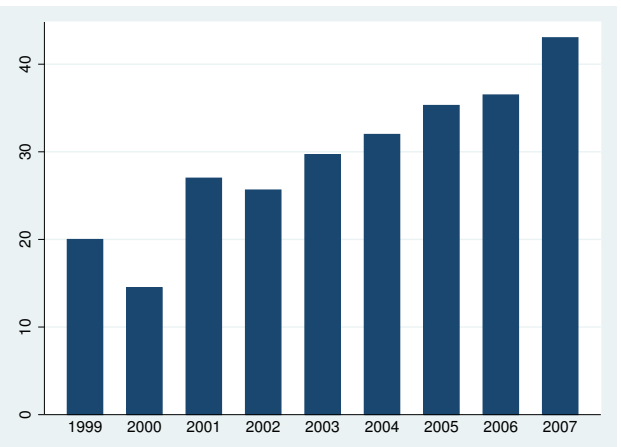

(e) No. of Pages Describing Collateral

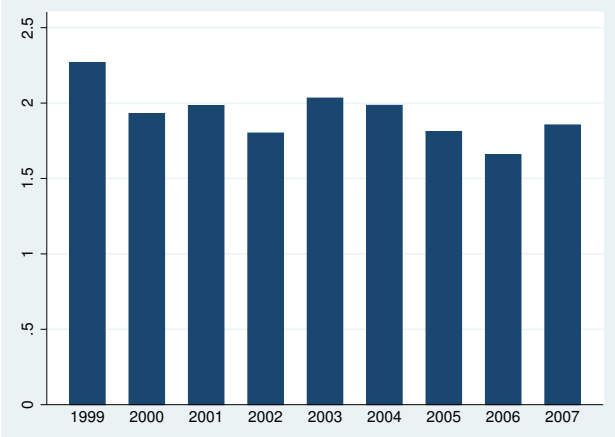

(b) No. of Loan Groups

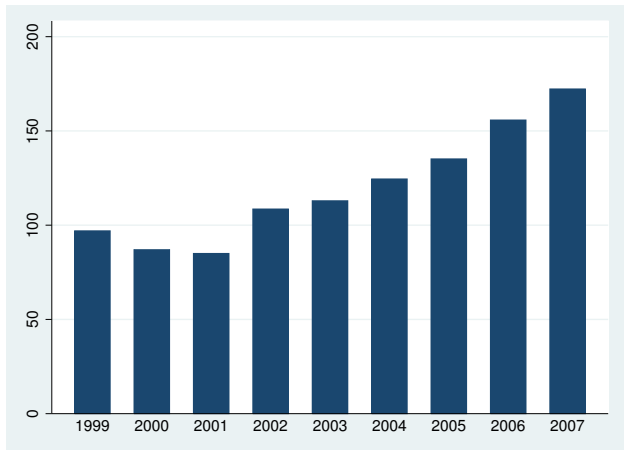

(d) No. of Pages in Prospectus Supplement

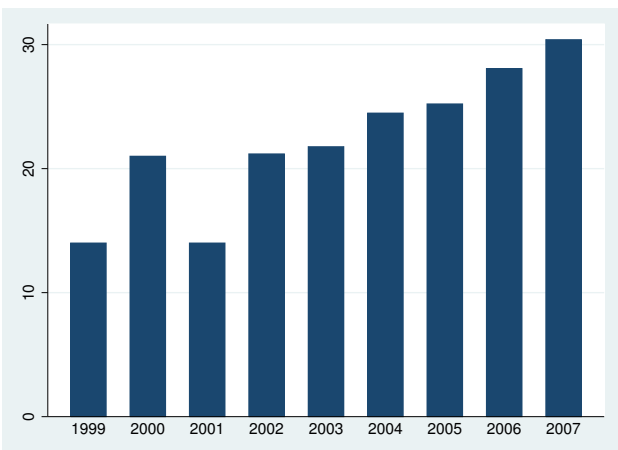

(f) No. of Pages Describing Waterfall

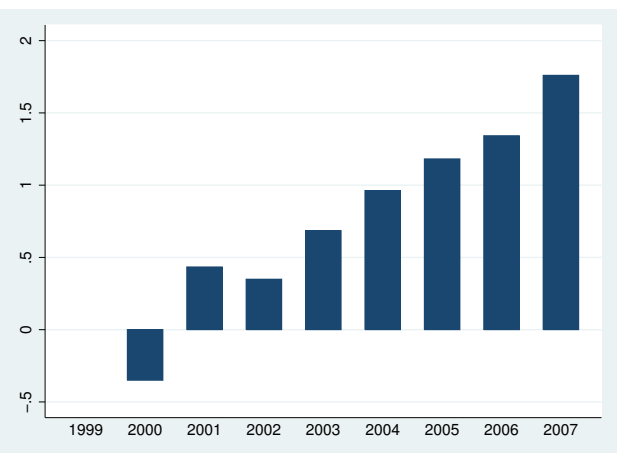

(g) Complexity Index 
Table 1: Summary Statistics

\begin{tabular}{|c|c|c|c|c|c|}
\hline Variable & Unique Obs. & Mean & Std. Dev. & Min. & Max. \\
\hline \multicolumn{6}{|l|}{ Panel A: Deal-Level Characteristics } \\
\hline nloangroups & 2377 & 1.84 & 0.89 & 1 & 11 \\
\hline loangroups2 & 2377 & 0.53 & 0.50 & 0 & 1 \\
\hline loangroups3ormore & 2377 & 0.12 & 0.32 & 0 & 1 \\
\hline ntranches & 2377 & 16 & 6 & 1 & 75 \\
\hline pagesprosup & 1477 & 143 & 38 & 27 & 391 \\
\hline pagesmpool & 1472 & 35 & 18 & 4 & 148 \\
\hline pageswaterfall & 1473 & 26 & 9 & 1 & 62 \\
\hline complexityindex & 1471 & 1.21 & 0.96 & -1.13 & 9.74 \\
\hline dealsize $(\$ \mathrm{M})$ & 2377 & 837 & 581 & 25 & 6,644 \\
\hline crosscollat & 1479 & 0.30 & 0.46 & 0 & 1 \\
\hline prospectusavailable & 2377 & 0.62 & 0.48 & 0 & 1 \\
\hline excessspread (\%) & 2332 & 4.65 & 2.21 & 0.02 & 26.20 \\
\hline leadtot $(\$ \mathrm{M})$ & 2377 & 26,197 & 18,447 & 86 & 75,265 \\
\hline \multicolumn{6}{|l|}{ Panel B: Security-Level Characteristics } \\
\hline$A A A$ & 24,375 & $36 \%$ & $48 \%$ & $0 \%$ & $100 \%$ \\
\hline$A A$ & 24,375 & $22 \%$ & $42 \%$ & $0 \%$ & $100 \%$ \\
\hline$A$ & 24,375 & $21 \%$ & $41 \%$ & $0 \%$ & $100 \%$ \\
\hline$B B B$ & 24,375 & $21 \%$ & $41 \%$ & $0 \%$ & $100 \%$ \\
\hline subordination (\%) & 23,262 & 12 & 8 & 0 & 98 \\
\hline spread (bp) & 23,461 & 92 & 89 & 0 & 625 \\
\hline disagreetranche & 24,375 & $24 \%$ & $43 \%$ & $0 \%$ & $100 \%$ \\
\hline default & 24,368 & $70 \%$ & $46 \%$ & $0 \%$ & $100 \%$ \\
\hline AAAdefault & 8,813 & $36 \%$ & $48 \%$ & $0 \%$ & $100 \%$ \\
\hline AAdefault & 5,458 & $80 \%$ & $40 \%$ & $0 \%$ & $100 \%$ \\
\hline Adefault & 5,053 & $95 \%$ & $22 \%$ & $0 \%$ & $100 \%$ \\
\hline BBBdefault & 5,044 & $95 \%$ & $22 \%$ & $0 \%$ & $100 \%$ \\
\hline \multicolumn{6}{|l|}{ Panel C: Group-Level Loan Characteristics } \\
\hline foreclosurerate $(\%)$ & 3737 & 14 & 7 & 0 & 100 \\
\hline fico & 2450 & 632 & 34 & 470 & 780 \\
\hline$l t v(\%)$ & 3771 & 78 & 13 & 0.10 & 118 \\
\hline lownodocshare (\%) & 2608 & 35 & 25 & 0 & 100 \\
\hline top5geoshare $(\%)$ & 3986 & 57 & 13 & 28 & 100 \\
\hline Cashare $(\%)$ & 3988 & 29 & 16 & 0 & 100 \\
\hline Flshare (\%) & 3988 & 9 & 5 & 0 & 89 \\
\hline Nyshare (\%) & 3988 & 4 & 5 & 0 & 39 \\
\hline Ilshare (\%) & 3988 & 3 & 3 & 0 & 21 \\
\hline Txshare (\%) & 3988 & 2 & 3 & 0 & 33 \\
\hline balunder300kshare (\%) & 3941 & 68 & 24 & 0 & 100 \\
\hline bal300600kshare (\%) & 3941 & 28 & 20 & 0 & 100 \\
\hline balover600kshare (\%) & 3941 & 4 & 7 & 0 & 65 \\
\hline wam (months) & 4116 & 341 & 38 & 136 & 477 \\
\hline
\end{tabular}


Notes: 1) The variable definitions are as follows. nloangroups is the number of loan groups in the deal; nloangroups2 equals 1 if the number of loan groups is exactly 2, 0 otherwise; nloangroups3ormore equals 1 if the number of loan groups is 3 or more, 0 otherwise; ntranches is the number of securities in the deal; pagesprosup is the number of pages in the prospectus supplement; pagesmpool is the number of pages in the prospectus supplement describing the collateral; pageswaterfall is the number of pages in the prospectus supplement describing the allocation of payments from collateral to the securities; complexityindex is the normalized first principal component of nloangroups, ntranches, pagesprosup, pagesmpool, and pageswaterfall; crosscollat is a dummy variable that takes a value of 1 if the deal provides for some cross-collateralization across loan groups; prospectusavail is a dummy variable indicating whether Bloomberg has a prospectus supplement for the deal; excessspread is the excess coupon the collateral pays relative to what is owed on the securities; leadtot is the volume of ABS deals in that year by the lead manager; subordination is the \% subordination the security has; spread is the coupon the security pays above one month LIBOR measured in basis points; disagreetranche takes a value of 1 if the ratings agencies disagree on the rating of that security; default equals 1 if the security has realized a principal loss or the ratings agencies have lowered their rating to that of a defaulted security; AAAdefault, AAdefault, Adefault, and BBBdefault summarize the default variable only for securities in that rating category; conforming takes a value of 1 if the description of the collateral group specifically refers to the loan group being conforming and takes a value of 0 if the description of the collateral group specifically states that the loan group is non-conforming; fico is the average FICO score of the loans at origination; $l t v$ is the average loan-to-value (LTV) of the loans at origination; lownodocshare is the fraction of loans that are No or Low documentation; top5geoshare is the fraction of loans that are in the 5 most common states for that pool; Cashare, Flshare, Nyshare, Ilshare, and Txshare is the sum of the share of loans from the most common 5 states in that deal that are in California, Florida, New York, Illinois, and Texas, respectively; balunder300kshare is the fraction of loans with original principal balances of under $\$ 300,000$; bal300600kshare is the fraction of loans with original principal balances of $\$ 300,000$ to $\$ 600,000$; balover600kshare is the fraction of loans with original principal balances of $\$ 600,000$; wam is the original weighted average maturity of the loans in months. 2) The sample is all USD-denominated private-label ABS deals backed by US collateral issued 1999-2007 for which detailed information is available via Bloomberg. 
Table 2: Correlations Between Complexity Variables

\begin{tabular}{rcccccc}
\hline & dealsize & nloangroups & ntranches & pagesprosup & pagesmpool & pageswaterfall \\
\hline dealsize & $100 \%$ & & & & & \\
nloangroups & $34 \%$ & $100 \%$ & & & & \\
ntranches & $33 \%$ & $52 \%$ & $100 \%$ & & & \\
pagesprosup & $28 \%$ & $40 \%$ & $46 \%$ & $100 \%$ & & \\
pagesmpool & $34 \%$ & $47 \%$ & $30 \%$ & $73 \%$ & $100 \%$ & $100 \%$ \\
pageswaterfall & $19 \%$ & $28 \%$ & $38 \%$ & $39 \%$ & $23 \%$ & \\
\hline
\end{tabular}

Notes: 1) nloangroups is the number of loan groups in the deal, ntranches is the number of securities in the deal, pagesprosup is the number of pages in the prospectus supplement, pagesmpool is the number of pages in the prospectus supplement describing the collateral, and pageswaterfall is the number of pages in the prospectus supplement describing the allocation of payments from collateral to the securities. 
Table 3: Complexity and Security Default

\begin{tabular}{|c|c|c|c|c|c|c|c|}
\hline Variables & (1) & $(2)$ & (3) & (4) & $(5)$ & (6) & (7) \\
\hline nloangroups & $\begin{array}{c}0.027^{* * *} \\
(0.004)\end{array}$ & & & & & $\begin{array}{c}0.015^{* * *} \\
(0.005)\end{array}$ & \\
\hline ntranches & & $\begin{array}{c}0.0026^{* * *} \\
(0.0006)\end{array}$ & & & & $\begin{array}{l}0.00019 \\
(0.0007)\end{array}$ & \\
\hline $\begin{array}{l}\text { pagesprosup } \\
\text { x100 }\end{array}$ & & & $\begin{array}{c}0.068^{* * *} \\
(0.008)\end{array}$ & & & $\begin{array}{c}0.047^{* * *} \\
(0.012)\end{array}$ & \\
\hline $\begin{array}{l}\text { pagesmpool } \\
\mathrm{x} 100\end{array}$ & & & & $\begin{array}{c}0.086^{* * *} \\
(0.015)\end{array}$ & & $\begin{array}{l}-0.010 \\
(0.021)\end{array}$ & \\
\hline $\begin{array}{l}\text { pageswaterfall } \\
\text { x100 }\end{array}$ & & & & & $\begin{array}{c}0.19 * * * \\
(0.03)\end{array}$ & $\begin{array}{c}0.11^{* * *} \\
(0.03)\end{array}$ & \\
\hline complexityindex & & & & & & & $\begin{array}{c}0.032^{* * *} \\
(0.003)\end{array}$ \\
\hline dealsize & $0.016^{* * *}$ & $0.022 * * *$ & $0.022^{* * *}$ & $0.025^{* * *}$ & $0.025^{* * *}$ & $0.015^{* * *}$ & $0.014^{* * *}$ \\
\hline x1000 & $(0.004)$ & $(0.004)$ & $(0.004)$ & $(0.004)$ & $(0.004)$ & $(0.004)$ & $(0.004)$ \\
\hline crosscollat & $\begin{array}{c}-0.016^{* * *} \\
(0.006)\end{array}$ & $\begin{array}{l}-0.009^{*} \\
(0.005)\end{array}$ & $\begin{array}{c}-0.012^{* *} \\
(0.005)\end{array}$ & $\begin{array}{c}-0.010^{*} \\
(0.005)\end{array}$ & $\begin{array}{l}-0.005 \\
(0.005)\end{array}$ & $\begin{array}{c}-0.017^{* * *} \\
(0.006)\end{array}$ & $\begin{array}{c}-0.017^{* * *} \\
(0.005)\end{array}$ \\
\hline $\begin{array}{l}\text { excessspread } \\
\mathrm{x} 100\end{array}$ & $\begin{array}{l}-0.13 \\
(0.16)\end{array}$ & $\begin{array}{c}0.05 \\
(0.16)\end{array}$ & $\begin{array}{c}0.25 \\
(0.15)\end{array}$ & $\begin{array}{l}0.29 * \\
(0.15)\end{array}$ & $\begin{array}{c}0.02 \\
(0.16)\end{array}$ & $\begin{array}{l}-0.18 \\
(0.17)\end{array}$ & $\begin{array}{l}-0.11 \\
(0.16)\end{array}$ \\
\hline leadtot & $0.028^{*}$ & $0.025^{*}$ & $0.024^{*}$ & 0.024 & $0.045^{* * *}$ & $0.036^{* *}$ & $0.030^{* *}$ \\
\hline x100000 & $(0.015)$ & $(0.015)$ & $(0.015)$ & $(0.015)$ & $(0.015)$ & $(0.015)$ & $(0.014)$ \\
\hline$A A A$ & $\begin{array}{c}-0.30^{* * *} \\
(0.02)\end{array}$ & $\begin{array}{c}-0.29^{* * *} \\
(0.02)\end{array}$ & $\begin{array}{c}-0.30^{* * *} \\
(0.02)\end{array}$ & $\begin{array}{c}-0.29^{* * *} \\
(0.02)\end{array}$ & $\begin{array}{c}-0.28^{* * *} \\
(0.02)\end{array}$ & $\begin{array}{c}-0.29^{* * *} \\
(0.02)\end{array}$ & $\begin{array}{c}-0.29^{* * *} \\
(0.02)\end{array}$ \\
\hline$A A$ & $\begin{array}{c}-0.12^{* * *} \\
(0.02)\end{array}$ & $\begin{array}{c}-0.11^{* * *} \\
(0.02)\end{array}$ & $\begin{array}{c}-0.11^{* * *} \\
(0.02)\end{array}$ & $\begin{array}{c}-0.11^{* * *} \\
(0.02)\end{array}$ & $\begin{array}{c}-0.11^{* * *} \\
(0.02)\end{array}$ & $\begin{array}{c}-0.11^{* * *} \\
(0.02)\end{array}$ & $\begin{array}{c}-0.11^{* * *} \\
(0.02)\end{array}$ \\
\hline$A$ & $\begin{array}{l}0.025^{*} \\
(0.014)\end{array}$ & $\begin{array}{l}0.026^{*} \\
(0.014)\end{array}$ & $\begin{array}{l}0.025^{*} \\
(0.014)\end{array}$ & $\begin{array}{c}0.031^{* *} \\
(0.014)\end{array}$ & $\begin{array}{c}0.032^{* *} \\
(0.014)\end{array}$ & $\begin{array}{c}0.030^{* *} \\
(0.014)\end{array}$ & $\begin{array}{c}0.031^{* *} \\
(0.014)\end{array}$ \\
\hline $\begin{array}{l}\text { subordination } \\
\text { x100 }\end{array}$ & $\begin{array}{c}-0.48^{* * * *} \\
(0.05)\end{array}$ & $\begin{array}{c}-0.51^{* * * *} \\
(0.05)\end{array}$ & $\begin{array}{c}-0.48^{* * *} \\
(0.05)\end{array}$ & $\begin{array}{c}-0.49^{* * *} \\
(0.05)\end{array}$ & $\begin{array}{c}-0.52^{* * *} \\
(0.05)\end{array}$ & $\begin{array}{c}-0.47^{* * *} \\
(0.05)\end{array}$ & $\begin{array}{c}-0.48^{* * *} \\
(0.05)\end{array}$ \\
\hline $\begin{array}{l}\text { spread (bp) } \\
\text { x100 }\end{array}$ & $\begin{array}{c}0.024^{* * *} \\
(0.008)\end{array}$ & $\begin{array}{c}0.025^{* * *} \\
(0.008)\end{array}$ & $\begin{array}{c}0.024^{* * *} \\
(0.007)\end{array}$ & $\begin{array}{c}0.028^{* * *} \\
(0.008)\end{array}$ & $\begin{array}{c}0.027^{* * *} \\
(0.008)\end{array}$ & $\begin{array}{c}0.027^{* * *} \\
(0.008)\end{array}$ & $\begin{array}{c}0.028^{* * *} \\
(0.008)\end{array}$ \\
\hline disagreetranche & $\begin{array}{c}0.057^{* * *} \\
(0.008)\end{array}$ & $\begin{array}{c}0.056^{* * *} \\
(0.008)\end{array}$ & $\begin{array}{c}0.057^{* * *} \\
(0.008)\end{array}$ & $\begin{array}{c}0.057^{* * *} \\
(0.008)\end{array}$ & $\begin{array}{c}0.057^{* * *} \\
(0.008)\end{array}$ & $\begin{array}{c}0.058^{* * *} \\
(0.008)\end{array}$ & $\begin{array}{c}0.057^{* * *} \\
(0.008)\end{array}$ \\
\hline Observations & 15,357 & 15,357 & 15,329 & 15,271 & 15,271 & 15,258 & 15,258 \\
\hline Year of Issue FEs & Yes & Yes & Yes & Yes & Yes & Yes & Yes \\
\hline Top 5 State Shares & Yes & Yes & Yes & Yes & Yes & Yes & Yes \\
\hline Pseudo- $R^{2}$ & 0.51 & 0.51 & 0.51 & 0.51 & 0.51 & 0.52 & 0.52 \\
\hline
\end{tabular}

Notes: 1) Entries shown are marginal effects from probit estimation of default on variables shown. 2) See notes to Table 1 for variable definitions. 3$)^{* * *}, * *$, and * denote statistical significance at the 1, 5, and $10 \%$ levels. 
Table 4: Complexity and Security Default: AAA Securities Only

\begin{tabular}{|c|c|c|c|c|c|c|c|}
\hline Variables & (1) & $(2)$ & $(3)$ & $(4)$ & $(5)$ & (6) & $(7)$ \\
\hline nloangroups & $\begin{array}{c}0.059^{* * *} \\
(0.0078)\end{array}$ & & & & & $\begin{array}{c}0.037^{* * *} \\
(0.0099)\end{array}$ & \\
\hline ntranches & & $\begin{array}{c}0.0037^{* * *} \\
(0.0013)\end{array}$ & & & & $\begin{array}{l}-0.0013 \\
(0.0015)\end{array}$ & \\
\hline $\begin{array}{l}\text { pagesprosup } \\
\mathrm{x} 100\end{array}$ & & & $\begin{array}{c}0.13^{* * *} \\
(0.02)\end{array}$ & & & $\begin{array}{c}0.06^{* *} \\
(0.03)\end{array}$ & \\
\hline $\begin{array}{l}\text { pagesmpool } \\
\mathrm{x} 100\end{array}$ & & & & $\begin{array}{c}0.23^{* * *} \\
(0.03)\end{array}$ & & $\begin{array}{c}0.07 \\
(0.05)\end{array}$ & \\
\hline $\begin{array}{l}\text { pageswaterfall } \\
\mathrm{x} 100\end{array}$ & & & & & $\begin{array}{c}0.34^{* * *} \\
(0.06)\end{array}$ & $\begin{array}{c}0.21^{* * *} \\
(0.06)\end{array}$ & \\
\hline complexityindex & & & & & & & $\begin{array}{c}0.068^{* * *} \\
(0.007)\end{array}$ \\
\hline $\begin{array}{l}\text { dealsize } \\
\mathrm{x} 1000\end{array}$ & $\begin{array}{c}0.028^{* * *} \\
(0.009)\end{array}$ & $\begin{array}{c}0.045^{* * *} \\
(0.009)\end{array}$ & $\begin{array}{c}0.037^{* * *} \\
(0.009)\end{array}$ & $\begin{array}{c}0.039^{* * *} \\
(0.009)\end{array}$ & $\begin{array}{c}0.045^{* * *} \\
(0.009)\end{array}$ & $\begin{array}{c}0.024^{* *} \\
(0.010)\end{array}$ & $\begin{array}{c}0.022^{* *} \\
(0.010)\end{array}$ \\
\hline crosscollat & $\begin{array}{c}-0.042^{* * *} \\
(0.012)\end{array}$ & $\begin{array}{c}-0.023^{*} \\
(0.012)\end{array}$ & $\begin{array}{c}-0.034^{* * *} \\
(0.012)\end{array}$ & $\begin{array}{c}-0.034^{* * *} \\
(0.012)\end{array}$ & $\begin{array}{l}-0.015 \\
(0.012)\end{array}$ & $\begin{array}{c}-0.043^{* * *} \\
(0.013)\end{array}$ & $\begin{array}{c}-0.045^{* * *} \\
(0.012)\end{array}$ \\
\hline $\begin{array}{l}\text { excessspread } \\
\text { x100 }\end{array}$ & $\begin{array}{c}0.83^{* *} \\
(0.37)\end{array}$ & $\begin{array}{c}1.50^{* * *} \\
(0.38)\end{array}$ & $\begin{array}{c}1.80^{* * *} \\
(0.34)\end{array}$ & $\begin{array}{c}2.00^{* * *} * \\
(0.35)\end{array}$ & $\begin{array}{c}1.40^{* * * *} \\
(0.35)\end{array}$ & $\begin{array}{l}1.00^{* *} \\
(0.40)\end{array}$ & $\begin{array}{c}0.91^{* *} \\
(0.36)\end{array}$ \\
\hline leadtot & $0.100^{* * *}$ & $0.094^{* * *}$ & $0.094^{* * *}$ & $0.096^{* * *}$ & $0.140^{* * *}$ & $0.120^{* * *}$ & $0.110^{* * *}$ \\
\hline x100000 & $(0.032)$ & $(0.032)$ & $(0.032)$ & $(0.032)$ & $(0.032)$ & $(0.032)$ & $(0.032)$ \\
\hline $\begin{array}{l}\text { subordination } \\
\mathrm{x} 100\end{array}$ & $\begin{array}{c}-0.68^{* * *} \\
(0.10)\end{array}$ & $\begin{array}{c}-0.76^{* * *} \\
(0.10)\end{array}$ & $\begin{array}{c}-0.71^{* * *} \\
(0.10)\end{array}$ & $\begin{array}{c}-0.72^{* * *} \\
(0.10)\end{array}$ & $\begin{array}{c}-0.76^{* * *} \\
(0.10)\end{array}$ & $\begin{array}{c}-0.68^{* * *} \\
(0.10)\end{array}$ & $\begin{array}{c}-0.70^{* * *} \\
(0.10)\end{array}$ \\
\hline spread (bp) & $0.58^{* * *}$ & $0.59 * * *$ & $0.59 * * *$ & $0.60 * * *$ & $0.58^{* * *}$ & $0.59 * * *$ & $0.60 * * *$ \\
\hline x100 & $(0.04)$ & $(0.04)$ & $(0.04)$ & $(0.04)$ & $(0.04)$ & $(0.04)$ & $(0.04)$ \\
\hline disagreetranche & $\begin{array}{c}0.047 \\
(0.041)\end{array}$ & $\begin{array}{c}0.041 \\
(0.041)\end{array}$ & $\begin{array}{c}0.046 \\
(0.041)\end{array}$ & $\begin{array}{c}0.038 \\
(0.041)\end{array}$ & $\begin{array}{c}0.039 \\
(0.041)\end{array}$ & $\begin{array}{c}0.042 \\
(0.041)\end{array}$ & $\begin{array}{c}0.036 \\
(0.041)\end{array}$ \\
\hline Observations & 5,194 & 5,194 & 5,183 & 5,158 & 5,158 & 5,153 & 5,153 \\
\hline Year of Issue FEs & Yes & Yes & Yes & Yes & Yes & Yes & Yes \\
\hline Top 5 State Shares & Yes & Yes & Yes & Yes & Yes & Yes & Yes \\
\hline Pseudo- $R^{2}$ & 0.38 & 0.37 & 0.38 & 0.37 & 0.37 & 0.38 & 0.38 \\
\hline
\end{tabular}

Notes: 1) Entries shown are marginal effects from probit estimation of default on variables shown. 2) See notes to Table 1 for variable definitions. 3) ***,**, and * denote statistical significance at the 1, 5, and $10 \%$ levels. 
Table 5: Complexity and Security Default: Sensitivity Analysis

\begin{tabular}{|c|c|c|c|c|c|c|c|}
\hline Variable & $(1)$ & $(2)$ & $(3)$ & $(4)$ & $(5)$ & (6) & $(7)$ \\
\hline complexityindex & $\begin{array}{c}0.032^{* * *} \\
(0.003)\end{array}$ & $\begin{array}{c}0.068^{* * *} \\
(0.007)\end{array}$ & $\begin{array}{c}0.013^{* * *} \\
(0.003)\end{array}$ & $\begin{array}{c}0.032^{* * *} \\
(0.005)\end{array}$ & $\begin{array}{c}0.023^{* * *} \\
(0.005)\end{array}$ & $\begin{array}{c}0.031^{* * *} \\
(0.003)\end{array}$ & $\begin{array}{c}0.021^{* * *} \\
(0.006)\end{array}$ \\
\hline dealsize & $0.014^{* * *}$ & $0.022^{* *}$ & $0.015^{* * *}$ & $0.014^{* *}$ & 0.011 & $0.014^{* * *}$ & 0.011 \\
\hline x1000 & $(0.004)$ & $(0.010)$ & $(0.004)$ & $(0.006)$ & $(0.007)$ & $(0.004)$ & $(0.008)$ \\
\hline crosscollat & $\begin{array}{c}-0.017^{* * *} \\
(0.005)\end{array}$ & $\begin{array}{c}-0.045^{* * *} \\
(0.012)\end{array}$ & $\begin{array}{l}-0.0068 \\
(0.005)\end{array}$ & $\begin{array}{c}-0.017^{* *} \\
(0.007)\end{array}$ & $\begin{array}{l}-0.007 \\
(0.008)\end{array}$ & $\begin{array}{c}-0.015^{* * *} \\
(0.006)\end{array}$ & $\begin{array}{l}-0.0061 \\
(0.009)\end{array}$ \\
\hline excessspread & -0.11 & $0.91^{* *}$ & $-0.50 * * *$ & -0.11 & 0.36 & -0.09 & 0.37 \\
\hline $\mathrm{x} 100$ & $(0.16)$ & $(0.36)$ & $(0.15)$ & $(0.27)$ & $(0.23)$ & $(0.16)$ & $(0.34)$ \\
\hline leadtot & $0.030 * *$ & $0.110^{* * *}$ & -0.008 & 0.030 & -0.008 & $0.035^{* *}$ & -0.005 \\
\hline x100000 & $(0.014)$ & $(0.032)$ & $(0.015)$ & $(0.020)$ & $(0.019)$ & $(0.015)$ & $(0.025)$ \\
\hline$A A A$ & $\begin{array}{c}-0.29^{* * *} \\
(0.02)\end{array}$ & & & $\begin{array}{c}-0.29 * * * \\
(0.02)\end{array}$ & $\begin{array}{c}-0.19 * * * \\
(0.03)\end{array}$ & $\begin{array}{c}-0.29^{* * *} \\
(0.02)\end{array}$ & $\begin{array}{c}-0.19^{* * *} \\
(0.03)\end{array}$ \\
\hline$A A$ & $\begin{array}{c}-0.11^{* * *} \\
(0.016)\end{array}$ & & $\begin{array}{c}-0.11^{* * *} \\
(0.01)\end{array}$ & $\begin{array}{c}-0.11^{* * *} \\
(0.02)\end{array}$ & $\begin{array}{c}-0.06^{* *} \\
(0.02)\end{array}$ & $\begin{array}{c}-0.11^{* * *} \\
(0.02)\end{array}$ & $\begin{array}{c}-0.06^{* *} \\
(0.03)\end{array}$ \\
\hline$A$ & $\begin{array}{c}0.031^{* *} \\
(0.014)\end{array}$ & & $\begin{array}{l}-0.006 \\
(0.010)\end{array}$ & $\begin{array}{c}0.031^{* *} \\
(0.015)\end{array}$ & $\begin{array}{c}0.074^{* * *} \\
(0.020)\end{array}$ & $\begin{array}{c}0.029^{* *} \\
(0.014)\end{array}$ & $\begin{array}{c}0.071^{* * *} \\
(0.021)\end{array}$ \\
\hline $\begin{array}{l}\text { subordination } \\
\text { x100 }\end{array}$ & $\begin{array}{c}-0.48^{* * *} \\
(0.05)\end{array}$ & $\begin{array}{c}-0.70^{* * *} \\
(0.10)\end{array}$ & $\begin{array}{c}-0.41^{* * *} \\
(0.05)\end{array}$ & $\begin{array}{c}-0.48^{* * *} \\
(0.08)\end{array}$ & $\begin{array}{c}-0.52^{* * *} \\
(0.06)\end{array}$ & $\begin{array}{c}-0.47^{* * *} \\
(0.05)\end{array}$ & $\begin{array}{c}-0.49 * * * \\
(0.10)\end{array}$ \\
\hline $\begin{array}{l}\text { spread (bp) } \\
\text { x100 }\end{array}$ & $\begin{array}{c}0.028^{* * *} * \\
(0.008)\end{array}$ & $\begin{array}{c}0.600^{* * *} * \\
(0.044)\end{array}$ & $\begin{array}{l}-0.007 \\
(0.005)\end{array}$ & $\begin{array}{c}0.028^{* * *} \\
(0.010)\end{array}$ & $\begin{array}{c}0.045^{* * *} \\
(0.011)\end{array}$ & $\begin{array}{c}0.026^{* * * *} \\
(0.007)\end{array}$ & $\begin{array}{c}0.043^{* * *} \\
(0.015)\end{array}$ \\
\hline disagreetranche & $\begin{array}{c}0.057^{* * *} * \\
(0.0075)\end{array}$ & $\begin{array}{c}0.036 \\
(0.041)\end{array}$ & $\begin{array}{c}0.035^{* * *} \\
(0.0052)\end{array}$ & $\begin{array}{c}0.057^{* * *} \\
(0.010)\end{array}$ & $\begin{array}{c}0.050^{* * *} \\
(0.010)\end{array}$ & $\begin{array}{c}0.055^{* * *} \\
(0.0074)\end{array}$ & $\begin{array}{c}0.048^{* * *} * \\
(0.013)\end{array}$ \\
\hline Observations & 15,258 & 5,153 & 10,105 & 15,258 & 8,165 & 14,596 & 7,793 \\
\hline Year of Issue FEs & Yes & Yes & Yes & Yes & Yes & Yes & Yes \\
\hline Top 5 State Shares & Yes & Yes & Yes & Yes & Yes & Yes & Yes \\
\hline Includes Conforming Pools & Yes & Yes & Yes & Yes & Yes & No & No \\
\hline Collateral Quality Controls & No & No & No & No & Yes & No & Yes \\
\hline Std. Errors Clustered by Deal & No & No & No & Yes & No & No & Yes \\
\hline AAA Only & No & Yes & No & No & No & No & No \\
\hline Pseudo- $R^{2}$ & 0.52 & 0.38 & 0.37 & 0.52 & 0.48 & 0.51 & 0.48 \\
\hline
\end{tabular}

Notes: 1) Entries shown are marginal effects from probit estimation of default on variables shown. 2) See notes to Table 1 for variable definitions. 3) ***, **, and * denote statistical significance at the 1,5 , and $10 \%$ levels. 4) Collateral Quality Controls are ltv, fico, lownodocshare, balunder300kshare, bal300600kshare, and wam. 5) In the specifications in Columns 6 and 7, we exclude securities collateralized primarily by loan groups indicated as conforming in the loan group description from Bloomberg. 
Table 6: The Pricing of Security Complexity

\begin{tabular}{|c|c|c|c|c|c|c|c|}
\hline Variable & (1) & $(2)$ & $(3)$ & (4) & $(5)$ & (6) & $(7)$ \\
\hline nloangroups & $\begin{array}{c}-1.60^{* * *} \\
(0.47)\end{array}$ & & & & & $\begin{array}{l}0.031 \\
(0.65)\end{array}$ & \\
\hline ntranches & & $\begin{array}{c}-0.31^{* * *} \\
(0.08)\end{array}$ & & & & $\begin{array}{c}-0.27^{* * *} \\
(0.10)\end{array}$ & \\
\hline pagesprosup & & & $\begin{array}{c}-0.039 * * * \\
(0.011)\end{array}$ & & & $\begin{array}{l}-0.009 \\
(0.017)\end{array}$ & \\
\hline pagesmpool & & & & $\begin{array}{c}-0.074^{* * *} \\
(0.021)\end{array}$ & & $\begin{array}{c}-0.055^{*} \\
(0.030)\end{array}$ & \\
\hline pageswaterfall & & & & & $\begin{array}{c}-0.028 \\
(0.040)\end{array}$ & $\begin{array}{c}0.024 \\
(0.042)\end{array}$ & \\
\hline complexityindex & & & & & & & $\begin{array}{c}-1.96 * * * \\
(0.45)\end{array}$ \\
\hline $\begin{array}{l}\text { dealsize } \\
\text { x100 }\end{array}$ & $\begin{array}{c}-0.23^{* * *} \\
(0.06)\end{array}$ & $\begin{array}{c}-0.23^{* * *} \\
(0.06)\end{array}$ & $\begin{array}{c}-0.26 \text { *** } \\
(0.06)\end{array}$ & $\begin{array}{c}-0.23^{* * *} \\
(0.06)\end{array}$ & $\begin{array}{c}-0.29 * * * \\
(0.06)\end{array}$ & $\begin{array}{c}-0.19 * * * \\
(0.06)\end{array}$ & $\begin{array}{c}-0.19 * * * \\
(0.06)\end{array}$ \\
\hline crosscollat & $\begin{array}{c}0.10 \\
(0.80)\end{array}$ & $\begin{array}{l}-0.02 \\
(0.78)\end{array}$ & $\begin{array}{l}-0.20 \\
(0.78)\end{array}$ & $\begin{array}{l}-0.10 \\
(0.78)\end{array}$ & $\begin{array}{l}-0.61 \\
(0.77)\end{array}$ & $\begin{array}{c}0.44 \\
(0.81)\end{array}$ & $\begin{array}{c}0.26 \\
(0.79)\end{array}$ \\
\hline excessspread & $\begin{array}{c}-0.67^{* * *} \\
(0.24)\end{array}$ & $\begin{array}{c}-0.60^{* *} \\
(0.24)\end{array}$ & $\begin{array}{c}-0.89^{* * *} * \\
(0.22)\end{array}$ & $\begin{array}{c}-1.00^{* * *} \\
(0.22)\end{array}$ & $\begin{array}{c}-0.93^{* * *} \\
(0.23)\end{array}$ & $\begin{array}{c}-0.71^{* * *} \\
(0.25)\end{array}$ & $\begin{array}{c}-0.68 * * * \\
(0.23)\end{array}$ \\
\hline leadtot & $\begin{array}{c}-0.085 \\
(0.22)\end{array}$ & $\begin{array}{c}-0.063 \\
(0.22)\end{array}$ & $\begin{array}{r}-0.067 \\
(0.22)\end{array}$ & $\begin{array}{r}-0.032 \\
(0.22)\end{array}$ & $\begin{array}{c}-0.082 \\
(0.22)\end{array}$ & $\begin{array}{c}-0.004 \\
(0.22)\end{array}$ & $\begin{array}{r}-0.088 \\
(0.22)\end{array}$ \\
\hline AAA Rated & $\begin{array}{c}-180^{* * *} \\
(1.58)\end{array}$ & $\begin{array}{c}-180^{* * *} \\
(1.58)\end{array}$ & $\begin{array}{c}-180^{* * *} \\
(1.58)\end{array}$ & $\begin{array}{c}-181^{* * *} \\
(1.58)\end{array}$ & $\begin{array}{c}-181^{* * *} \\
(1.58)\end{array}$ & $\begin{array}{c}-180 * * * \\
(1.59)\end{array}$ & $\begin{array}{c}-180 * * * \\
(1.59)\end{array}$ \\
\hline AA Rated & $\begin{array}{c}-155^{* * *} \\
(1.24)\end{array}$ & $\begin{array}{c}-155^{* * *} \\
(1.24)\end{array}$ & $\begin{array}{c}-155^{* * *} \\
(1.24)\end{array}$ & $\begin{array}{c}-155^{* * *} \\
(1.24)\end{array}$ & $\begin{array}{c}-155^{* * *} \\
(1.24)\end{array}$ & $\begin{array}{c}-155^{* * *} \\
(1.25)\end{array}$ & $\begin{array}{c}-155^{* * *} \\
(1.24)\end{array}$ \\
\hline A Rated & $\begin{array}{c}-109 * * * \\
(1.09)\end{array}$ & $\begin{array}{c}-109 * * * \\
(1.09)\end{array}$ & $\begin{array}{c}-109 * * * \\
(1.09)\end{array}$ & $\begin{array}{c}-109^{* * *} \\
(1.09)\end{array}$ & $\begin{array}{c}-109 * * * \\
(1.09)\end{array}$ & $\begin{array}{c}-109 * * * \\
(1.09)\end{array}$ & $\begin{array}{c}-109 * * * \\
(1.09)\end{array}$ \\
\hline subordination & $\begin{array}{l}-0.062 \\
(0.080)\end{array}$ & $\begin{array}{l}-0.055 \\
(0.079)\end{array}$ & $\begin{array}{l}-0.059 \\
(0.080)\end{array}$ & $\begin{array}{l}-0.031 \\
(0.080)\end{array}$ & $\begin{array}{l}-0.019 \\
(0.079)\end{array}$ & $\begin{array}{l}-0.055 \\
(0.080)\end{array}$ & $\begin{array}{l}-0.055 \\
(0.080)\end{array}$ \\
\hline disagreetranche & $\begin{array}{c}14.4^{* * *} \\
(0.88)\end{array}$ & $\begin{array}{c}14.5^{* * *} \\
(0.88)\end{array}$ & $\begin{array}{c}14.4^{* * *} \\
(0.88)\end{array}$ & $\begin{array}{c}14.3^{* * *} \\
(0.88)\end{array}$ & $\begin{array}{c}14.3^{* * *} \\
(0.88)\end{array}$ & $\begin{array}{c}14.4^{* * *} \\
(0.88)\end{array}$ & $\begin{array}{c}14.3^{* * *} \\
(0.88)\end{array}$ \\
\hline Constant & $\begin{array}{c}243^{* * *} \\
(3.41)\end{array}$ & $\begin{array}{c}243^{* * *} \\
(3.41)\end{array}$ & $\begin{array}{c}246^{* * *} \\
(3.51)\end{array}$ & $\begin{array}{c}244^{* * *} \\
(3.43)\end{array}$ & $\begin{array}{c}243^{* * *} \\
(3.44)\end{array}$ & $\begin{array}{c}244^{* * *} \\
(3.57)\end{array}$ & $\begin{array}{c}240^{* * *} \\
(3.46)\end{array}$ \\
\hline Observations & 15,357 & 15,357 & 15,329 & 15,271 & 15,271 & 15,258 & 15,258 \\
\hline$R^{2}$ & 0.757 & 0.757 & 0.757 & 0.757 & 0.757 & 0.757 & 0.757 \\
\hline Year of Issue FEs & Yes & Yes & Yes & Yes & Yes & Yes & Yes \\
\hline Top 5 State Shares & Yes & Yes & Yes & Yes & Yes & Yes & Yes \\
\hline
\end{tabular}

Notes: 1) Entries shown are coefficients from a regression of the spread of the security, in basis points, relative to one month LIBOR on the variables shown. 2) See notes to Table 1 for variable definitions. 3) ***, **, and * denote statistical significance at the 1,5 , and $10 \%$ levels. 
Table 7: Subordination Levels (Credit Support) for AAA Securities and Complexity

\begin{tabular}{|c|c|c|c|c|c|c|c|}
\hline Variables & (1) & $(2)$ & $(3)$ & $(4)$ & $(5)$ & $(6)$ & $(7)$ \\
\hline nloangroups & $\begin{array}{c}-0.50 * * * \\
(0.09)\end{array}$ & & & & & $\begin{array}{c}-0.76^{* * *} \\
(0.12)\end{array}$ & \\
\hline ntranches & & $\begin{array}{c}0.010 \\
(0.015)\end{array}$ & & & & $\begin{array}{c}0.094^{* * * *} \\
(0.019)\end{array}$ & \\
\hline pagesprosup & & & $\begin{array}{c}-0.012^{* * *} \\
(0.002)\end{array}$ & & & $\begin{array}{c}-0.017^{* * *} \\
(0.004)\end{array}$ & \\
\hline pagesmpool & & & & $\begin{array}{c}-0.012^{* * *} \\
(0.005)\end{array}$ & & $\begin{array}{c}0.021^{* * *} \\
(0.007)\end{array}$ & \\
\hline pageswaterfall & & & & & $\begin{array}{c}0.003 \\
(0.009)\end{array}$ & $\begin{array}{c}0.019^{* *} \\
(0.009)\end{array}$ & \\
\hline complexityindex & & & & & & & $\begin{array}{r}-0.37^{* * *} \\
(0.090)\end{array}$ \\
\hline $\begin{array}{l}\text { dealsize } \\
\text { x1000 }\end{array}$ & $\begin{array}{c}-0.32^{* *} \\
(0.13)\end{array}$ & $\begin{array}{c}-0.47^{* * *} \\
(0.13)\end{array}$ & $\begin{array}{c}-0.43^{* * *} \\
(0.13)\end{array}$ & $\begin{array}{c}-0.57^{* * *} \\
(0.13)\end{array}$ & $\begin{array}{c}-0.67^{* * *} \\
(0.13)\end{array}$ & $\begin{array}{c}-0.59^{* * *} \\
(0.14)\end{array}$ & $\begin{array}{c}-0.48^{* * *} \\
(0.14)\end{array}$ \\
\hline crosscollat & $\begin{array}{c}-0.97^{* * *} \\
(0.17)\end{array}$ & $\begin{array}{c}-1.30^{* * *} \\
(0.17)\end{array}$ & $\begin{array}{c}-1.10^{* * *} \\
(0.17)\end{array}$ & $\begin{array}{c}-1.17^{* * *} \\
(0.17)\end{array}$ & $\begin{array}{c}-1.26^{* * *} \\
(0.17)\end{array}$ & $\begin{array}{c}-0.94^{* * *} \\
(0.18)\end{array}$ & $\begin{array}{c}-1.06^{* * *} \\
(0.17)\end{array}$ \\
\hline excessspread & $\begin{array}{c}0.50^{* * *} \\
(0.049)\end{array}$ & $\begin{array}{c}0.38^{* * *} \\
(0.049)\end{array}$ & $\begin{array}{c}0.43^{* * *} \\
(0.047)\end{array}$ & $\begin{array}{c}0.42^{* * *} \\
(0.047)\end{array}$ & $\begin{array}{c}0.43^{* * *} \\
(0.049)\end{array}$ & $\begin{array}{c}0.46^{* * *} \\
(0.052)\end{array}$ & $\begin{array}{c}0.48^{* * *} \\
(0.049)\end{array}$ \\
\hline $\begin{array}{l}\text { leadtot } \\
\text { x10000 }\end{array}$ & $\begin{array}{c}-0.47^{* * *} \\
(0.05)\end{array}$ & $\begin{array}{c}-0.46^{* * *} \\
(0.05)\end{array}$ & $\begin{array}{c}-0.46^{* * *} \\
(0.05)\end{array}$ & $\begin{array}{c}-0.47^{* * *} \\
(0.05)\end{array}$ & $\begin{array}{c}-0.46^{* * *} \\
(0.05)\end{array}$ & $\begin{array}{c}-0.46^{* * *} \\
(0.05)\end{array}$ & $\begin{array}{c}-0.47^{* * *} \\
(0.05)\end{array}$ \\
\hline disagreetranche & $\begin{array}{c}-1.85^{* * *} \\
(0.60)\end{array}$ & $\begin{array}{c}-1.87^{* * *} \\
(0.60)\end{array}$ & $\begin{array}{c}-1.85^{* * *} \\
(0.60)\end{array}$ & $\begin{array}{c}-1.78^{* * *} \\
(0.60)\end{array}$ & $\begin{array}{c}-1.82^{* * *} \\
(0.60)\end{array}$ & $\begin{array}{c}-2.02^{* * *} \\
(0.60)\end{array}$ & $\begin{array}{c}-1.78^{* * *} \\
(0.60)\end{array}$ \\
\hline Constant & $\begin{array}{c}11.4^{* * *} \\
(0.71)\end{array}$ & $\begin{array}{c}12.2^{* * *} \\
(0.67)\end{array}$ & $\begin{array}{c}12.4^{* * *} \\
(0.74)\end{array}$ & $\begin{array}{c}11.6^{* * *} \\
(0.72)\end{array}$ & $\begin{array}{c}11.3^{* * *} \\
(0.72)\end{array}$ & $\begin{array}{c}12.0^{* * *} \\
(0.75)\end{array}$ & $\begin{array}{c}10.9^{* * *} \\
(0.72)\end{array}$ \\
\hline Observations & 5,527 & 5,527 & 5,516 & 5,490 & 5,490 & 5,485 & 5,485 \\
\hline$R^{2}$ & 0.154 & 0.147 & 0.154 & 0.152 & 0.151 & 0.163 & 0.154 \\
\hline Year of Issue FEs & Yes & Yes & Yes & Yes & Yes & Yes & Yes \\
\hline Top 5 State Shares & Yes & Yes & Yes & Yes & Yes & Yes & Yes \\
\hline
\end{tabular}

Notes: 1) Entries shown are coefficients from a regression of the subordination of the security, in percent, on the variables shown. 2) See notes to Table 1 for variable definitions. 3) ***, **, and * denote statistical significance at the 1, 5, and $10 \%$ levels. 4) Regressions include only AAA securities. 
Table 8: Subordination Levels (Credit Support) and Complexity: Sensitivity Analysis

\begin{tabular}{|c|c|c|c|c|c|c|}
\hline Variable & (1) & $(2)$ & $(3)$ & $(4)$ & $(5)$ & $(6)$ \\
\hline \multirow[t]{2}{*}{ nloangroups } & $-0.50 * * *$ & $-0.52^{* * *}$ & & & & \\
\hline & $(0.086)$ & $(0.090)$ & & & & \\
\hline complexityindex & & & $\begin{array}{c}-0.37^{* * *} \\
(0.090)\end{array}$ & $\begin{array}{c}-0.40^{* * *} \\
(0.095)\end{array}$ & $\begin{array}{c}-0.37^{* *} \\
(0.18)\end{array}$ & $\begin{array}{c}-0.54^{* * *} \\
(0.065)\end{array}$ \\
\hline AAA Rated & & & & & & $\begin{array}{c}6.25^{* * *} \\
(0.13)\end{array}$ \\
\hline dealsize & $-0.32^{* *}$ & $-0.39 * * *$ & $-0.48^{* * *}$ & $-0.49 * * *$ & $-0.48^{* *}$ & $-0.32^{* * *}$ \\
\hline $\mathrm{x} 1000$ & $(0.13)$ & $(0.14)$ & $(0.14)$ & $(0.15)$ & $(0.24)$ & $(0.10)$ \\
\hline crosscollat & $\begin{array}{c}-0.97^{* * *} \\
(0.17)\end{array}$ & $\begin{array}{c}-1.10^{* * *} \\
(0.19)\end{array}$ & $\begin{array}{c}-1.06^{* * *} \\
(0.17)\end{array}$ & $\begin{array}{c}-1.23^{* * *} \\
(0.19)\end{array}$ & $\begin{array}{c}-1.06^{* * *} \\
(0.34)\end{array}$ & $\begin{array}{c}-0.84^{* * *} \\
(0.12)\end{array}$ \\
\hline excessspread & $\begin{array}{c}0.50 * * * \\
(0.05)\end{array}$ & $\begin{array}{c}0.51^{* * *} \\
(0.05)\end{array}$ & $\begin{array}{c}0.48^{* * *} \\
(0.05)\end{array}$ & $\begin{array}{c}0.48^{* * *} \\
(0.05)\end{array}$ & $\begin{array}{c}0.48^{* * *} \\
(0.12)\end{array}$ & $\begin{array}{c}0.54^{* * *} \\
(0.04)\end{array}$ \\
\hline leadtot & $\begin{array}{c}-0.47^{* * *} \\
(0.05)\end{array}$ & $\begin{array}{c}-0.47^{* * *} \\
(0.05)\end{array}$ & $\begin{array}{c}-0.47^{* * *} \\
(0.05)\end{array}$ & $\begin{array}{c}-0.47^{* * *} \\
(0.05)\end{array}$ & $\begin{array}{c}-0.47^{* * *} \\
(0.08)\end{array}$ & $\begin{array}{c}-0.49^{* * *} \\
(0.03)\end{array}$ \\
\hline disagreetranche & $\begin{array}{c}-1.85^{* * *} \\
(0.60)\end{array}$ & $\begin{array}{c}-1.91^{* * *} \\
(0.63)\end{array}$ & $\begin{array}{c}-1.78^{* * *} * \\
(0.60)\end{array}$ & $\begin{array}{c}-1.84^{* * *} \\
(0.63)\end{array}$ & $\begin{array}{c}-1.78^{* * *} * \\
(0.57)\end{array}$ & $\begin{array}{c}-2.76^{* * *} \\
(0.17)\end{array}$ \\
\hline Constant & $\begin{array}{c}11.4^{* * *} \\
(0.7)\end{array}$ & $\begin{array}{c}11.2^{* * *} \\
(0.7)\end{array}$ & $\begin{array}{c}10.9^{* * *} \\
(0.7)\end{array}$ & $\begin{array}{c}10.6^{* * *} \\
(0.8)\end{array}$ & $\begin{array}{c}10.9 * * * \\
(1.2)\end{array}$ & $\begin{array}{c}5.58 * * * \\
(0.5)\end{array}$ \\
\hline Observations & 5,527 & 4,881 & 5,485 & 4,851 & 5,485 & 9,134 \\
\hline$R^{2}$ & 0.154 & 0.156 & 0.154 & 0.155 & 0.154 & 0.396 \\
\hline Year of Issue FEs & Yes & Yes & Yes & Yes & Yes & Yes \\
\hline Top 5 State Shares & Yes & Yes & Yes & Yes & Yes & Yes \\
\hline Includes Conforming Pools & Yes & No & Yes & No & Yes & Yes \\
\hline Std. Errors Clustered by Deal & No & No & No & No & Yes & No \\
\hline AAA Only & Yes & Yes & Yes & Yes & Yes & No \\
\hline
\end{tabular}

Notes: 1) Entries shown are coefficients from a regression of the subordination of the security, in percent, on the variables shown. 2) See notes to Table 1 for variable definitions. 3) ***, **, and * denote statistical significance at the 1, 5, and $10 \%$ levels. 4) In the specifications in Columns 2 and 4, we exclude securities collateralized primarily by loan groups indicated as conforming in the loan group description from Bloomberg. 5) Regressions in Columns 1 through 5 include only AAA securities. 6) The regression in Column 6 includes AAA and AA securities. 
Table 9: Are Loan Groups Tailored?

\begin{tabular}{lccc}
\hline Loan Group Characteristic & Inter-Deal MAD & Intra-Deal MAD & T-Stat for Difference \\
\hline Cashare & 12.5 & 7.1 & 29.3 \\
Flshare & 2.9 & 1.4 & 27.4 \\
Nyshare & 3.9 & 1.6 & 37.0 \\
Ilshare & 3.0 & 1.3 & 45.7 \\
Txshare & 2.7 & 1.0 & 45.2 \\
fico & 25.3 & 8.7 & 30.7 \\
ltv & 6.0 & 1.1 & 24.2 \\
lownodocshare & 18.4 & 3.7 & 40.6 \\
balunder300kshare & 19.2 & 17.1 & 6.7 \\
bal300600kshare & 15.7 & 13.8 & 6.5 \\
balover600kshare & 4.3 & 3.4 & 8.5 \\
wam & 22.0 & 4.2 & 32.5 \\
\hline
\end{tabular}

Notes: 1) MAD is mean absolute deviation. 2) See Table 1 for variable definitions. 
Table 10: Complexity and Collateral Quality

\begin{tabular}{|c|c|c|c|c|c|c|c|}
\hline Variables & (1) & $(2)$ & (3) & (4) & $(5)$ & (6) & $(7)$ \\
\hline nloangroups & $\begin{array}{c}0.09 \\
(0.14)\end{array}$ & & & & & $\begin{array}{c}-0.37^{* *} \\
(0.19)\end{array}$ & \\
\hline ntranches & & $\begin{array}{c}0.037 \\
(0.025)\end{array}$ & & & & $\begin{array}{c}0.053^{*} \\
(0.031)\end{array}$ & \\
\hline pagesprosup & & & $\begin{array}{c}0.0078^{*} \\
(0.0045)\end{array}$ & & & $\begin{array}{c}-0.0120^{*} \\
(0.0070)\end{array}$ & \\
\hline pagesmpool & & & & $\begin{array}{c}0.031^{* * *} \\
(0.009)\end{array}$ & & $\begin{array}{c}0.052^{* * *} \\
(0.014)\end{array}$ & \\
\hline pageswaterfall & & & & & $\begin{array}{c}0.053^{* * *} \\
(0.016)\end{array}$ & $\begin{array}{c}0.052^{* * *} \\
(0.016)\end{array}$ & \\
\hline complexityindex & & & & & & & $\begin{array}{c}0.44^{* * *} \\
(0.16)\end{array}$ \\
\hline dealsize & 0.095 & 0.051 & -0.010 & -0.210 & 0.034 & -0.250 & -0.13 \\
\hline x1000 & $(0.290)$ & $(0.290)$ & $(0.300)$ & $(0.300)$ & $(0.290)$ & $(0.310)$ & $(0.300)$ \\
\hline crosscollat & $\begin{array}{c}0.49 \\
(0.34)\end{array}$ & $\begin{array}{c}0.47 \\
(0.33)\end{array}$ & $\begin{array}{c}0.47 \\
(0.33)\end{array}$ & $\begin{array}{c}0.38 \\
(0.33)\end{array}$ & $\begin{array}{c}0.66^{* *} \\
(0.33)\end{array}$ & $\begin{array}{l}0.58^{*} \\
(0.34)\end{array}$ & $\begin{array}{c}0.39 \\
(0.33)\end{array}$ \\
\hline excessspread & $\begin{array}{c}0.28^{* * *} \\
(0.09)\end{array}$ & $\begin{array}{c}0.24^{* * *} \\
(0.09)\end{array}$ & $\begin{array}{c}0.28^{* * *} \\
(0.08)\end{array}$ & $\begin{array}{c}0.30 * * * \\
(0.08)\end{array}$ & $\begin{array}{l}0.18^{* *} \\
(0.09)\end{array}$ & $\begin{array}{l}0.22^{* *} \\
(0.10)\end{array}$ & $\begin{array}{c}0.20^{* *} \\
(0.09)\end{array}$ \\
\hline $\begin{array}{l}\text { leadtot } \\
\text { (x10000) }\end{array}$ & $\begin{array}{c}-0.30^{* * *} \\
(0.10)\end{array}$ & $\begin{array}{c}-0.30^{* * *} \\
(0.10)\end{array}$ & $\begin{array}{c}-0.31^{* * *} \\
(0.10)\end{array}$ & $\begin{array}{c}-0.32^{* * *} \\
(0.10)\end{array}$ & $\begin{array}{c}-0.25^{* * *} \\
(0.10)\end{array}$ & $\begin{array}{c}-0.28^{* * *} \\
(0.10)\end{array}$ & $\begin{array}{c}-0.30^{* * *} * \\
(0.10)\end{array}$ \\
\hline Constant & $\begin{array}{c}26.9^{* * *} \\
(6.2)\end{array}$ & $\begin{array}{c}27.9^{* * *} \\
(6.2)\end{array}$ & $\begin{array}{c}27.5^{* * *} \\
(6.2)\end{array}$ & $\begin{array}{c}27.2^{* * *} \\
(6.1)\end{array}$ & $\begin{array}{c}27.1^{* * *} \\
(6.1)\end{array}$ & $\begin{array}{c}28.1^{* * *} \\
(6.2)\end{array}$ & $\begin{array}{c}29.3^{* * *} \\
(6.2)\end{array}$ \\
\hline Observations & 1,271 & 1,271 & 1,271 & 1,264 & 1,265 & 1,262 & 1,262 \\
\hline$R^{2}$ & 0.496 & 0.497 & 0.497 & 0.503 & 0.501 & 0.510 & 0.501 \\
\hline Year of Issue FEs & Yes & Yes & Yes & Yes & Yes & Yes & Yes \\
\hline Top 5 State Shares & Yes & Yes & Yes & Yes & Yes & Yes & Yes \\
\hline Collateral Quality Controls & Yes & Yes & Yes & Yes & Yes & Yes & Yes \\
\hline
\end{tabular}

Notes: 1) Entries shown are coefficients from a regression of the foreclosure rate on the loan group, in percent, on the variables shown. 2) See notes to Table 1 for variable definitions. 3) ***, **, and * denote statistical significance at the 1, 5, and 10\% levels. 4) Collateral Quality Controls are ltv, fico, lownodocshare, balunder300kshare, bal300600kshare, and wam. 